\title{
Metal-mediated catalysis in the gas phase: A review
}

\author{
Xiao-Na Li a, Xiu-Ping Zou a,b, Sheng-Gui He ${ }^{\text {a,* }}$ \\ a Beijing National Laboratory for Molecular Sciences, State Key Laboratory for Structural Chemistry of Unstable and Stable Species, Institute of Chemistry, \\ Chinese Academy of Sciences, Beijing 100190, China \\ b School of Chemistry and Chemical Engineering, South China University of Technology, Guangzhou 510641, Guangdong, China
}

\section{A R T I C L E I N F O}

Article history:

Received 31 November 2016

Accepted 5 January 2017

Published 5 September 2017

\section{Keywords:}

Metal catalysis

Clusters

Single atom catalysts

Carbon monoxide

Methane

\begin{abstract}
A B S T R A C T
This review summarizes a variety of experimentally identified gas-phase catalytic cycles, all of which are mediated by atomic metal ions, bare metal clusters, metal oxide clusters or metal complexes. Emphasis is placed on the latest advances in the unique catalytic reactivity of cluster-confined single noble metal atoms. The cycles discussed in this paper cover a wide range of inorganic and organic molecules. The use of start-of-the-art mass spectrometric instrumentation in conjunction with quantum chemistry calculations is also reported, as these techniques have determined the mechanistic details of the elementary steps of such catalytic cycles. The important role of gas-phase data in guiding the rational design of better-performing catalysts in related condensed phase reactions is also examined. In particular, this review focuses on the following three topics: (1) the catalytic oxidation of carbon monoxide, (2) the catalytic functionalization of methane, and (3) catalytic decarboxylation.
\end{abstract}

(C) 2017, Dalian Institute of Chemical Physics, Chinese Academy of Sciences. Published by Elsevier B.V. All rights reserved.

\section{Introduction}

Metal-based catalysts are employed in numerous industrial $[1,2]$ and biological processes [3-5], and are indispensable in lowering the energy barriers to chemical reactions that are thermodynamically favorable but kinetically slow under ambient conditions. The future development of catalysts with desirable properties under mild conditions will require fundamental insights into the elementary steps of catalytic processes at the molecular level. However, a comprehensive understanding of the mechanistic details of these elementary steps is still far off, as a result of the enormous complexity of so-called "real-life" catalytic environments. Under actual conditions, aggregation, solvent effects, counterions and surface defects all obscure the nature of the catalytic active sites and of intermediate species. Thus, the design of better-performing catalysts with tailored properties remains a challenge.

Advanced mass spectrometry instrumentation combined with state-of-the-art theoretical calculations provides a powerful means of probing the energetics and kinetics of complex gas-phase chemical processes [6-22]. Gas-phase experiments can be performed under isolated, controlled and reproducible conditions and, in this unperturbed environment, the difficult-to-control or poorly defined parameters in real-life catalytic usage can be excluded. Many such gas-phase studies have examined the key steps in industrially and biologically important catalytic cycles, focusing on electronic structures, vital intermediates and the oxidation states of metal centers. Several excellent reviews have summarized gas-phase catalytic cycles $[7,23]$, cooperative effects in clusters [24] and important elementary reactions, such as $\mathrm{CO}$ oxidation [15], $\mathrm{CO}_{2}$ transformation [25], $\mathrm{CH}_{4}$ functionalization [26] and decarboxylation

\footnotetext{
* Corresponding author. Tel: +86-10-62536990; Fax: +86-10-62559373; E-mail: shengguihe@iccas.ac.cn This work was supported by the National Natural Science Foundation of China $(21303215,21325215,21573246)$, the Major Research Plan of China (No. 2013CB834603) and the grant from the Youth Innovation Promotion Association, Chinese Academy of Sciences (2016030).

DOI: 10.1016/S1872-2067(17)62782-7| http://www.sciencedirect.com/science/journal/18722067 | Chin. J. Catal., Vol. 38, No. 9, September 2017
} 
reactions $[27,28]$. The focus of the present article is a review of the latest advances in gas-phase catalytic reactions, with an emphasis on cluster-confined single-atom catalysts. These materials serve as an ideal model to explore the nature of actual single-atom catalysts that allow the most efficient use of noble metals and show great potential for high activity and good product selectivity $[29,30]$. This review may assist in providing a clear understanding of structure-property relationships in various catalytic processes. This paper also presents an unambiguous identification of both the catalytic active sites and the reaction mechanisms that govern various catalytic reactions and may facilitate the further development of efficient catalysts. The following three topics are discussed in detail: (1) the catalytic oxidation of carbon monoxide, (2) the catalytic functionalization of methane, and (3) catalytic decarboxylation. The reactions discussed herein span a wide range of inorganic and organic molecules, including $\mathrm{CO}, \mathrm{CH}_{4}, \mathrm{H}_{2}, \mathrm{C}_{2} \mathrm{H}_{2}, \mathrm{C}_{2} \mathrm{H}_{4}, \mathrm{C}_{6} \mathrm{H}_{6}, \mathrm{CH}_{3} \mathrm{OH}$, $\mathrm{HCOOH}$ and $\mathrm{CH}_{3} \mathrm{COOH}$. The experimentally-identified gas-phase catalytic reactions mediated by metal species and involving atomic metal ions, bare metal clusters, metal oxide clusters or metal complexes are summarized in Table 1.

\section{Catalytic oxidation of carbon monoxide}

The oxidation of $\mathrm{CO}$ to $\mathrm{CO}_{2}$ is not only an important process for the removal of $\mathrm{CO}$ from the atmosphere but also is a typical heterogeneous process [86]. Metals or metal oxides play significant roles in this oxidation, both as catalysts and catalytic support materials $[86,87]$. However, despite extensive experimental and theoretical studies of bare or supported metal catalysts, the catalytically-active oxygen species [88-90], the oxidation states of the metals [29,91-93], the importance of the perimeter interface [94-96] and other factors are still debated. In this regard, gas-phase clusters serve as ideal models for studying the mechanistic details of the catalytic oxidation of $\mathrm{CO}$ in the condensed phase. Some important gas-phase studies of the elementary steps and catalytic cycles of CO oxidation have been reviewed [15], and there have also been several recent reports $[16,97]$. In this section, the latest advances in our understanding of the catalytic cycles during $\mathrm{CO}$ oxidation are presented, with an emphasis on the unique catalytic reactivity of single noble atoms confined by atomic clusters.

\subsection{Catalytic oxidation of $\mathrm{CO}$ by $\mathrm{N}_{2} \mathrm{O}$}

The catalytic conversion of $\mathrm{CO}$ by $\mathrm{N}_{2} \mathrm{O}$ is of great importance, both environmentally and economically, because it removes harmful gases generated during fossil fuel combustion [98-100]. Although exothermic, the reaction between CO and $\mathrm{N}_{2} \mathrm{O}$ will not proceed spontaneously either at ambient or elevated temperatures. Thus, metal-based heterogeneous catalysts are indispensable in lowering the energy barrier and promoting the reaction.

Since the groundbreaking work of Kappes et al. [31] in 1981 regarding the catalytic oxidation of $\mathrm{CO}$ by $\mathrm{N}_{2} \mathrm{O}\left(\mathrm{N}_{2} \mathrm{O}+\mathrm{CO} \rightarrow \mathrm{CO}_{2}\right.$ $+\mathrm{N}_{2}$ ) with a single $\mathrm{Fe}^{+}$ion as a catalyst, the catalytic conversion of $\mathrm{CO}$ by $\mathrm{N}_{2} \mathrm{O}$ mediated by atomic metal cations has been exten- sively studied [32,33,36,37] (Table 1 ). Such catalysis has also been reviewed [7]. In total, 59 atomic metal cations have been systematically examined to obtain a comprehensive understanding of their catalytic reactivity, including the fourth-row ions from $\mathrm{K}^{+}$to $\mathrm{Se}^{+}$, fifth-row ions from $\mathrm{Rb}^{+}$to $\mathrm{Te}^{+}$(excluding $\mathrm{Tc}^{+}$), sixth-row ions from $\mathrm{Cs}^{+}$to $\mathrm{Bi}^{+}$, and the lanthanide ions (excluding $\mathrm{Pm}^{+}$) $[36,101,102]$. The oxidation of $\mathrm{CO}$ by $\mathrm{N}_{2} \mathrm{O}$ involves the transfer of an $\mathrm{O}$ atom from $\mathrm{N}_{2} \mathrm{O}$ to $\mathrm{CO}$, and thus the metal cation $\left(\mathrm{M}^{+}\right)$must exhibit an $\mathrm{O}$ atom affinity (OA) intermediate between the $\mathrm{OA}$ values of $\mathrm{N}_{2}(1.74 \mathrm{eV})$ and $\mathrm{CO}$ (5.51 $\mathrm{eV}$ ) in order to have the thermodynamic potential to catalyze the reaction. Therefore, the catalysis requires $\mathrm{OA}\left(\mathrm{N}_{2}: 1.74 \mathrm{eV}\right)$ $<\mathrm{OA}\left(\mathrm{M}^{+}\right)<\mathrm{OA}(\mathrm{CO}: 5.51 \mathrm{eV})$, sometimes referred to as the "thermodynamic window of opportunity" [36]. Among the 59 cations studied to date, 26 cations fall within this window, although only 10 exhibit catalytic activity $\left(\mathrm{Ca}^{+}, \mathrm{Fe}^{+}, \mathrm{Ge}^{+}, \mathrm{Sr}^{+}, \mathrm{Ba}^{+}\right.$, $\mathrm{Os}^{+}, \mathrm{Ir}^{+}, \mathrm{Pt}^{+}, \mathrm{Eu}^{+}$, and $\mathrm{Yb}^{+}[36]$, as shown in Fig. 1). The remaining $16 \mathrm{Cr}^{+}, \mathrm{Mn}^{+}, \mathrm{Co}^{+}, \mathrm{Ni}^{+}, \mathrm{Cu}^{+}, \mathrm{Se}^{+}, \mathrm{Mo}^{+}, \mathrm{Rn}^{+}, \mathrm{Rh}^{+}, \mathrm{Sn}^{+}, \mathrm{Te}^{+}, \mathrm{Re}^{+}$, $\mathrm{Pb}^{+}, \mathrm{Bi}^{+}, \mathrm{Tm}^{+}$, and $\left.\mathrm{Lu}^{+}\right)$do not sufficiently increase the oxidation rate at room temperature, either during the formation of the metal oxide, $\mathrm{MO}^{+}$, or during the subsequent reduction of this oxide by $\mathrm{CO}$. The catalytic oxidation of $\mathrm{CO}$ by $\mathrm{N}_{2} \mathrm{O}$ is not thermodynamically controlled but has an intrinsic reaction barrier that can reduce the efficiency of exothermic 0 atom transfer catalysis [102]. In addition to $\mathrm{N}_{2} \mathrm{O}$, several metal cations $\left(\mathrm{Fe}^{+}\right.$, $\mathrm{Os}^{+}$, and $\mathrm{Ir}^{+}$) can also catalyze the oxidation of $\mathrm{CO}$ by $\mathrm{NO}$ and $\mathrm{NO}_{2}$ (Table 1).

In recent years, there has been increasing interest in the catalysis of $\mathrm{CO}$ oxidation by $\mathrm{N}_{2} \mathrm{O}$ using poly-atomic cluster ions [35,38-41,103], metal oxide clusters [40], and bimetallic oxide cluster ions $[42,45]$ (Table 1). There has been an emphasis on the importance of the single electron localized atomic oxygen radical $\left(\mathrm{O}^{-}\right)$during the elementary steps comprising $\mathrm{CO}$ oxidation, such as when employing clusters including $\mathrm{Zr}_{n} \mathrm{O}_{2 n}{ }^{+}(n=$ 1-4) [40], $\mathrm{Ti}_{2} \mathrm{O}_{4}{ }^{+}$[41], $\mathrm{AlVO}_{4}{ }^{+}[42,104], \mathrm{VO}_{3}{ }^{+}$[44], and $\mathrm{YAlO}_{3}{ }^{+}$ [45]. As an example, Fig. 2 shows the catalytic cycle mediated by the $\mathrm{AlVO}_{4}{ }^{+} / \mathrm{AlVO}_{3}{ }^{+}$couple [42]. In this mechanism, the carbon atom in $\mathrm{CO}$ approaches and then abstracts the central radical oxygen in $\mathrm{AlVO}_{4}{ }^{+}$to generate $\mathrm{CO}_{2}$ and $\mathrm{AlVO}_{3}{ }^{+}$. The high reactivity of atomic oxygen radicals toward CO $[16,105,106]$ and many other inorganic and organic molecules has been previously demonstrated $[13,26]$. Following the CO oxidation, the reductive cluster $\mathrm{AlVO}_{3}{ }^{+}$can be transformed back to $\mathrm{AlVO}_{4}{ }^{+}$ using $\mathrm{N}_{2} \mathrm{O}$ as the oxidizing agent to complete the catalytic cycle. An interesting aspect of this process is that the highly reactive $\mathrm{O}^{-\bullet}$ is bonded to the main-group $\mathrm{Al}$ atom rather than the transition-metal $\mathrm{V}$ atom [104]. This is in sharp contrast to the traditional understanding of the $\mathrm{V}_{2} \mathrm{O}_{5} / \mathrm{Al}_{2} \mathrm{O}_{3}$ catalyst, in which the $\mathrm{V}_{2} \mathrm{O}_{5}$ component is almost always considered to be the active phase that induces the catalytic reactions. Therefore, the support materials in these widely-used vanadium oxide catalysts, which are normally considered to be inactive, may in fact participate directly in chemical reactions [107-109].

The above studies indicate that a single atomic metal ion can be sufficiently active so as to promote the oxidation of $\mathrm{CO}$ by $\mathrm{N}_{2} \mathrm{O}$ because of the relatively low $\mathrm{OA}$ of $\mathrm{N}_{2}$. However, this is not the case for the catalytic oxidation of $\mathrm{CO}$ by molecular $\mathrm{O}_{2}$, as 
Table 1

A summary of experimentally-identified gas-phase catalytic cycles.

\begin{tabular}{|c|c|c|c|c|c|}
\hline Reaction & Catalysts & Year and Ref. & Reaction & Catalysts & Year and Ref. \\
\hline \multicolumn{3}{|c|}{ Catalytic oxidation of carbon monoxide } & \multicolumn{3}{|l|}{ Catalytic decarboxylation } \\
\hline \multirow[t]{28}{*}{$\mathrm{CO}+\mathrm{N}_{2} \mathrm{O} \rightarrow \mathrm{CO}_{2}+\mathrm{N}_{2}$} & $\mathrm{Fe}^{+}, \mathrm{FeO}^{+}$ & $1981[31]$ & $\mathrm{CH}_{3} \mathrm{COOH} \rightarrow \mathrm{H}_{2} \mathrm{O}+\mathrm{C}_{2} \mathrm{H}_{2} \mathrm{O}$ & $\mathrm{W}_{2} \mathrm{O}_{6}(\mathrm{OH})^{-}$ & $2003[64]$ \\
\hline & $\mathrm{Pt}^{+}, \mathrm{PtO}_{2}^{+}$ & $2001[32]$ & & $\mathrm{Mo}_{2} \mathrm{O}_{6}(\mathrm{OH})^{-}$ & $2003[64]$ \\
\hline & $\mathrm{Os}^{+}, \mathrm{OsO}^{+}$ & $2003[33]$ & & $\mathrm{WO}_{3}(\mathrm{OH})^{-}$ & $2003[64]$ \\
\hline & $\mathrm{Fe}^{+}, \mathrm{FeO}^{+}$ & $2003[33]$ & & $\mathrm{MoO}_{3}(\mathrm{OH})^{-}$ & $2003[64]$ \\
\hline & $\mathrm{Ir}^{+}, \mathrm{IrO}^{+}$ & $2003[33]$ & $\mathrm{CH}_{3} \mathrm{COOH} \rightarrow \mathrm{CH}_{4}+\mathrm{CO}_{2}$ & $\mathrm{CH}_{3} \mathrm{MgCl}_{2}^{-}$ & $2004[65]$ \\
\hline & $\mathrm{Pt}_{7} \mathrm{O}_{0-3}{ }^{+}$ & $2003[33]$ & & $\mathrm{CH}_{3} \mathrm{Mg}\left(\mathrm{O}_{2} \mathrm{CCH}_{3}\right)_{2}^{-}$ & $2004[65]$ \\
\hline & $\mathrm{Pt}_{n} \mathrm{O}_{m}^{-}(n=3-6, m=0-2)$ & $1998[34]$ & $\mathrm{HCOOH} \rightarrow \mathrm{H}_{2}+\mathrm{CO}_{2}$ & $\mathrm{HMgCl}_{2}^{-}$ & $2006[66]$ \\
\hline & $\mathrm{Pt}_{n} \mathrm{O}_{m}^{-}(n=3-6, m=0-2)$ & $2004[35]$ & & $\mathrm{HMg}\left(\mathrm{HCO}_{2}\right)_{2}^{-}$ & $2006[66]$ \\
\hline & $\mathrm{Fe}^{+}, \mathrm{FeO}^{+}$ & $2005[36]$ & $\mathrm{HCOOH} \rightarrow \mathrm{H}_{2}+\mathrm{CO}_{2}$ & {$\left[\mathrm{Ph}_{3} \mathrm{PAg}_{2}(\mathrm{H})\right]^{+}$} & $2016[67]$ \\
\hline & $\mathrm{Ge}^{+}, \mathrm{GeO}^{+}$ & $2005[36]$ & $\mathrm{C}_{3} \mathrm{H}_{5} \mathrm{O}_{2} \mathrm{CCH}_{3} \rightarrow \mathrm{C}_{3} \mathrm{H}_{5} \mathrm{CH}_{3}+\mathrm{CO}_{2}$ & $\mathrm{CH}_{3} \mathrm{CuCH}_{3}^{-}$ & $2012[68]$ \\
\hline & $\mathrm{Sr}^{+}, \mathrm{SrO}^{+}$ & $2005[36]$ & & $\mathrm{CH}_{3} \mathrm{CO}_{2} \mathrm{Cu}_{2}^{+}$ & $2013[69]$ \\
\hline & $\mathrm{Ca}^{+}, \mathrm{CaO}^{+}$ & $2005[36]$ & & $\mathrm{CH}_{3} \mathrm{CO}_{2} \mathrm{CuAg}^{+}$ & $2013[69]$ \\
\hline & $\mathrm{Ba}^{+}, \mathrm{BaO}^{+}$ & $2005[36]$ & & $\mathrm{CH}_{3} \mathrm{CO}_{2} \mathrm{Ag}_{2}^{+}$ & $2013[69]$ \\
\hline & $\mathrm{Eu}^{+}, \mathrm{EuO}^{+}$ & $2005[36]$ & Catalytic carbon-carbon coupling & & \\
\hline & $\mathrm{Yb}^{+}, \mathrm{YbO}^{+}$ & $2005[36]$ & $2 c-\mathrm{C}_{3} \mathrm{H}_{6} \rightarrow \mathrm{C}_{6} \mathrm{H}_{6}+3 \mathrm{H}_{2}$ & $\mathrm{Fe}_{4}^{+}$ & $1991[70]$ \\
\hline & $\mathrm{OsO}_{0-4}^{+}$ & $2005[36]$ & & $\mathrm{Fe}_{4}^{+}$ & $1992[71]$ \\
\hline & $\mathrm{IrO}_{0-3}{ }^{+}$ & $2005[36]$ & $3 \mathrm{C}_{2} \mathrm{H}_{4} \rightarrow \mathrm{C}_{6} \mathrm{H}_{6}+3 \mathrm{H}_{2}$ & $\mathrm{~W}^{+}$ & $1994[72]$ \\
\hline & $\mathrm{PtO}_{0-3}{ }^{+}$ & $2005[36]$ & & $\mathrm{U}^{+}$ & $1995[73]$ \\
\hline & $\mathrm{Fe}\left(\mathrm{C}_{6} \mathrm{H}_{6}\right)_{1,2}{ }^{+}, \mathrm{FeO}\left(\mathrm{C}_{6} \mathrm{H}_{6}\right)_{1,2^{+}}$ & $2006[37]$ & $\mathrm{C}_{2} \mathrm{H}_{2}+\mathrm{C}_{4} \mathrm{H}_{6} \rightarrow \mathrm{C}_{6} \mathrm{H}_{6}+\mathrm{H}_{2}$ & $\mathrm{Ru}^{+}$ & $1997[74]$ \\
\hline & $\mathrm{Pt}_{4} \mathrm{O}_{0-3}^{-}$ & $2007[38]$ & & $\mathrm{Rh}^{+}$ & $1997[74]$ \\
\hline & $\mathrm{Al}_{2} \mathrm{O}_{2}{ }^{+}, \mathrm{Al}_{2} \mathrm{O}_{3}{ }^{+}$ & 2008 [39] & Other catalytic oxygen-atom transfer reac & tions & \\
\hline & $\mathrm{Al}_{2} \mathrm{O}_{2-4^{-}}$ & $2008[39]$ & $\mathrm{O}_{3}+\mathrm{O} \rightarrow 2 \mathrm{O}_{2}$ & $\mathrm{Mg}^{+}$ & $1968[75]$ \\
\hline & $\mathrm{Zr}_{n} \mathrm{O}_{2 n-1}{ }^{+}, \mathrm{Zr}_{n} \mathrm{O}_{2 n}{ }^{+}(n=1-4)$ & $2008[40]$ & $\mathrm{C}_{2} \mathrm{H}_{6}+2 \mathrm{~N}_{2} \mathrm{O} \rightarrow \mathrm{CH}_{3} \mathrm{CHO}+\mathrm{H}_{2} \mathrm{O}+2 \mathrm{~N}_{2}$ & $\mathrm{Fe}^{+}$ & $1990[76]$ \\
\hline & $\mathrm{Ti}_{2} \mathrm{O}_{3}{ }^{+}, \mathrm{Ti}_{2} \mathrm{O}_{4}{ }^{+}$ & $2011[41]$ & $\mathrm{C}_{2} \mathrm{H}_{2}+\mathrm{N}_{2} \mathrm{O} \rightarrow \mathrm{C}_{2} \mathrm{H}_{2} \mathrm{O}+\mathrm{N}_{2}$ & $\mathrm{Ca}^{+}$ & $2006[77]$ \\
\hline & $\mathrm{AlVO}_{3}{ }^{+}, \mathrm{AlVO}_{4}{ }^{+}$ & 2011 [42] & & $\begin{array}{c}\mathrm{Zr}_{n} \mathrm{O}_{2 n-1}{ }^{+}, \mathrm{Zr}_{n} \mathrm{O}_{2 n}{ }^{+} \\
(n=1-4)\end{array}$ & 2008 [40] \\
\hline & $\mathrm{Rh}_{n} \mathrm{O}_{m}(n=10-28, m=0-5)$ & 2012 [43] & & $\mathrm{Ti}_{2} \mathrm{O}_{4}^{+}, \mathrm{Ti}_{2} \mathrm{O}_{3}{ }^{+}$ & $2011[41]$ \\
\hline & $\mathrm{VO}_{2}, \mathrm{VO}_{3}$ & $2013[44]$ & $\mathrm{C}_{2} \mathrm{H}_{2}+2 \mathrm{~N}_{2} \mathrm{O} \rightarrow \mathrm{CH}_{2} \mathrm{O}+2 \mathrm{~N}_{2}+\mathrm{CO}$ & $\mathrm{Fe}^{+}, \mathrm{FeO}^{+}$ & $1981[31]$ \\
\hline & $\mathrm{YAlO}_{2}{ }^{+}, \mathrm{YAlO}_{3}{ }^{+}$ & $2013[45]$ & & $\mathrm{Sr}^{+}$ & $2006[77]$ \\
\hline \multirow[t]{3}{*}{$2 \mathrm{CO}+2 \mathrm{NO} \rightarrow \mathrm{N}_{2}+2 \mathrm{CO}_{2}$} & $\mathrm{Fe}^{+}, \mathrm{FeO}^{+}$ & $2003[33]$ & & $\mathrm{Ba}^{+}$ & $2006[77]$ \\
\hline & $\mathrm{Os}^{+}, \mathrm{OsO}^{+}$ & $2003[33]$ & $2 \mathrm{C}_{3} \mathrm{H}_{4}+\mathrm{O}_{2} \rightarrow \mathrm{C}_{6} \mathrm{H}_{4}+2 \mathrm{H}_{2} \mathrm{O}_{2}$ & $\mathrm{Mn}_{2} \mathrm{O}_{2}^{+}$ & $2002[78]$ \\
\hline & $\mathrm{Ir}^{+}, \mathrm{IrO}^{+}$ & $2003[33]$ & $\mathrm{C}_{3} \mathrm{H}_{6}+\mathrm{N}_{2} \mathrm{O} \rightarrow \mathrm{C}_{3} \mathrm{H}_{6} \mathrm{O}+\mathrm{N}_{2}$ & $\mathrm{Ti}_{2} \mathrm{O}_{4}{ }^{+}, \mathrm{Ti}_{2} \mathrm{O}_{3}{ }^{+}$ & $2011[41]$ \\
\hline \multirow[t]{4}{*}{$\mathrm{CO}+\mathrm{NO}_{2} \rightarrow \mathrm{NO}+\mathrm{CO}_{2}$} & $\mathrm{Fe}^{+}, \mathrm{FeO}^{+}$ & $2003[33]$ & $\mathrm{C}_{6} \mathrm{H}_{6}+\mathrm{N}_{2} \mathrm{O} \rightarrow \mathrm{C}_{6} \mathrm{H}_{5} \mathrm{OH}+\mathrm{N}_{2}$ & $\mathrm{Cr}^{+}$ & 1994 [79] \\
\hline & $\mathrm{Os}^{+}, \mathrm{OsO}^{+}$ & $2003[33]$ & & $\mathrm{Mn}^{+}$ & $1994[79]$ \\
\hline & $\mathrm{Ir}^{+}, \mathrm{IrO}^{+}$ & $2003[33]$ & & $\mathrm{Co}^{+}$ & $1994[79]$ \\
\hline & $\mathrm{Mn}_{2} \mathrm{O}_{4}, \mathrm{Mn}_{2} \mathrm{O}_{5}$ & $2013[46]$ & $\mathrm{C}_{6} \mathrm{H}_{6}+\mathrm{O}_{2} \rightarrow \mathrm{C}_{6} \mathrm{H}_{4} \mathrm{O}+\mathrm{H}_{2} \mathrm{O}$ & $\mathrm{Cr}^{+}$ & $2002[80]$ \\
\hline \multirow[t]{9}{*}{$2 \mathrm{CO}+\mathrm{O}_{2} \rightarrow 2 \mathrm{CO}_{2}$} & $\mathrm{Pt}_{n} \mathrm{O}_{m}^{-}(n=3-6, m=0-2)$ & $1998[34]$ & & $\mathrm{V}^{+}$ & $2002[80]$ \\
\hline & $\mathrm{Au}_{6}^{-}$ & $2002[47]$ & & $\mathrm{Fe}^{+}$ & $2002[80]$ \\
\hline & $\mathrm{Au}_{2}{ }^{-}, \mathrm{Au}_{2} \mathrm{O}_{2}^{-}$ & $2001[48]$ & & $\operatorname{Re}^{+}$ & $2002[80]$ \\
\hline & $\mathrm{Au}_{2}^{-}, \mathrm{Au}_{2} \mathrm{O}_{2}^{-}$ & $2003[49]$ & $2 \mathrm{CH}_{3} \mathrm{OH}+\mathrm{O}_{2} \rightarrow 2 \mathrm{CH}_{2} \mathrm{O}+2 \mathrm{H}_{2} \mathrm{O}$ & $\mathrm{Mn}_{2} \mathrm{O}_{2}^{+}$ & $2002[78]$ \\
\hline & $\mathrm{Ag}_{n}^{-}, \mathrm{Ag}_{n} \mathrm{O}_{4}^{-}(n=7,9,11)$ & $2004[50]$ & & $\mathrm{VO}_{4}^{-}, \mathrm{VO}_{3}^{-}$ & $2006[81]$ \\
\hline & $\mathrm{Au}_{3}(\mathrm{CO})_{2-5}$ & $2011[51]$ & $\mathrm{CH}_{3} \mathrm{CHO}+\mathrm{O}_{2} \rightarrow \mathrm{CH}_{3} \mathrm{CO}+\mathrm{H}_{2} \mathrm{O}_{2}$ & $\mathrm{Mn}_{2} \mathrm{O}_{2}^{+}$ & $2002[78]$ \\
\hline & $\mathrm{Pd}_{6} \mathrm{O}_{3-5}{ }^{+}$ & $2012[52]$ & $\mathrm{H}_{2}+\mathrm{N}_{2} \mathrm{O} \rightarrow \mathrm{H}_{2} \mathrm{O}+\mathrm{N}_{2}$ & $\mathrm{Fe}^{+}, \mathrm{FeO}^{+}$ & $1997[58]$ \\
\hline & $\mathrm{AuAl}_{3} \mathrm{O}_{3-5}{ }^{+}$ & 2014 [53] & & $\mathrm{Fe}^{+}$ & $2008[82]$ \\
\hline & $\mathrm{PtAl}_{3} \mathrm{O}_{5-7^{-}}$ & $2015[54]$ & & $\mathrm{Os}^{+}$ & $2008[82]$ \\
\hline \multicolumn{3}{|c|}{ Catalytic functionalization of methane } & & $\mathrm{Ir}^{+}$ & $2008[82]$ \\
\hline $\mathrm{CH}_{4}+\mathrm{O}_{2} \rightarrow \mathrm{CH}_{2} \mathrm{O}+\mathrm{H}_{2} \mathrm{O}$ & $\mathrm{OsO}_{2}^{+}$ & $1989[55]$ & & $\mathrm{Pt}^{+}$ & $2008[82]$ \\
\hline $\mathrm{CH}_{4}+\mathrm{N}_{2} \mathrm{O} \rightarrow \mathrm{CH}_{3} \mathrm{OH}+\mathrm{N}_{2}$ & $\mathrm{Fe}^{+}, \mathrm{FeO}^{+}$ & $1990[56]$ & $2 \mathrm{H}_{2}+\mathrm{O}_{2} \rightarrow 2 \mathrm{H}_{2} \mathrm{O}$ & $\mathrm{Pt}_{n}(n=7-30)$ & $2002[83]$ \\
\hline $2 \mathrm{CH}_{4}+\mathrm{O}_{2} \rightarrow \mathrm{CH}_{2} \mathrm{O}+\mathrm{CH}_{3} \mathrm{OH}+\mathrm{H}_{2}$ & $\mathrm{Pt}^{+}$ & $1994[57]$ & Other cycles & & \\
\hline $\mathrm{CH}_{4}+\mathrm{O}_{2} \rightarrow \mathrm{CH}_{2} \mathrm{O}_{2}+\mathrm{H}_{2}$ & $\mathrm{Pt}^{+}$ & $1994[57]$ & $\mathrm{C}_{2} \mathrm{H}_{4}+\mathrm{NH}_{3}+\mathrm{N}_{2} \mathrm{O} \rightarrow \mathrm{C}_{2} \mathrm{H}_{4} \mathrm{NH}+\mathrm{N}_{2}+\mathrm{H}_{2} \mathrm{O}$ & $\mathrm{Fe}^{+}$ & $1988[84]$ \\
\hline $\mathrm{CH}_{4}+\mathrm{N}_{2} \mathrm{O} \rightarrow \mathrm{CH}_{3} \mathrm{OH}+\mathrm{N}_{2}$ & $\mathrm{Fe}^{+}, \mathrm{FeO}^{+}$ & $1997[58]$ & $\mathrm{CH}_{3} \mathrm{OH}+\mathrm{CH}_{3} \mathrm{NO}_{2} \rightarrow \mathrm{CH}_{2} \mathrm{O}+\mathrm{H}_{2} \mathrm{O}+\mathrm{CH}_{3} \mathrm{NO}$ & {$\left[\mathrm{Mo}_{2} \mathrm{O}_{6}(\mathrm{OH})\right]^{-}$} & $2003[85]$ \\
\hline $\mathrm{CH}_{4}+\mathrm{H}_{2} \mathrm{O} \rightarrow 3 \mathrm{H}_{2}+\mathrm{CO}$ & $\mathrm{Pt}^{+}$ & 1999 [59] & & & \\
\hline $\mathrm{CH}_{4}+\mathrm{O}_{3} \rightarrow \mathrm{O}_{2}+\mathrm{CH}_{3} \mathrm{OH}$ & $\mathrm{Ni}^{+}$ & $2010[60]$ & & & \\
\hline $\mathrm{CH}_{4}+\mathrm{O}_{3} \rightarrow \mathrm{O}_{2}+\mathrm{CH}_{3} \mathrm{OH}$ & $\mathrm{Pd}^{+}$ & $2010[60]$ & & & \\
\hline $2 \mathrm{CH}_{4} \rightarrow \mathrm{C}_{2} \mathrm{H}_{4}+2 \mathrm{H}_{2}$ & $\mathrm{Au}_{2}^{+}$ & $2010[61]$ & & & \\
\hline $2 \mathrm{CH}_{4} \rightarrow \mathrm{C}_{2} \mathrm{H}_{4}+2 \mathrm{H}_{2}(\mathrm{HT})$ & $\mathrm{Au}_{2}^{+}$ & $2011[62]$ & & & \\
\hline $\mathrm{CH}_{4}+\mathrm{O}_{2} \rightarrow \mathrm{CH}_{2} \mathrm{O}+\mathrm{H}_{2} \mathrm{O}(\mathrm{LT})$ & $\mathrm{Au}_{2}{ }^{+}$ & $2011[62]$ & & & \\
\hline $2 \mathrm{CD}_{4} \rightarrow \mathrm{C}_{2} \mathrm{D}_{4}+2 \mathrm{D}_{2}$ & $\mathrm{Au}_{2}^{+}$ & $2013[63]$ & & & \\
\hline $2 \mathrm{CD}_{4} \rightarrow \mathrm{C}_{2} \mathrm{D}_{4}+2 \mathrm{D}_{2}$ & $\mathrm{Pd}_{2}^{+}$ & $2013[63]$ & & & \\
\hline
\end{tabular}

discussed in Section 2.2.

\subsection{Catalytic oxidation of CO by molecular $\mathrm{O}_{2}$}

Molecular $\mathrm{O}_{2}$ activation is generally considered to represent the critical step in catalytic CO oxidation [110]. Because the bond enthalpy of molecular $\mathrm{O}_{2}(\mathrm{O}-\mathrm{O}=5.16 \mathrm{eV})$ is much greater 


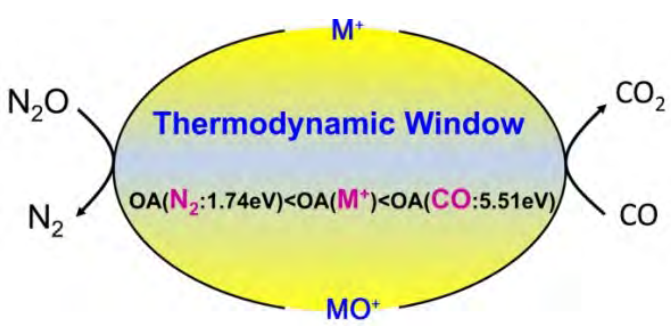

Fig. 1. Catalytic oxidation of $\mathrm{CO}$ by $\mathrm{N}_{2} \mathrm{O}$ mediated by atomic metal cations $\mathrm{M}^{+}\left(\mathrm{M}^{+}=\mathrm{Ca}^{+}, \mathrm{Fe}^{+}, \mathrm{Ge}^{+}, \mathrm{Sr}^{+}, \mathrm{Ba}^{+}, \mathrm{Os}^{+}, \mathrm{Ir}^{+}, \mathrm{Pt}^{+}, \mathrm{Eu}^{+}\right.$, and $\left.\mathrm{Yb}^{+}\right)$, adapted from Ref. [36].

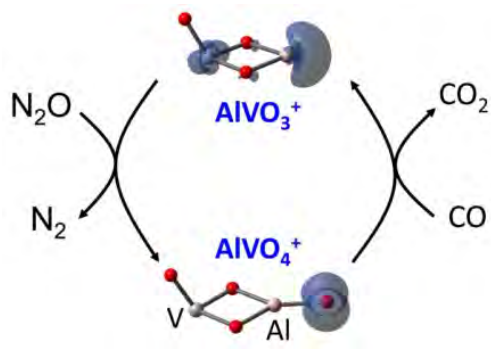

Fig. 2. Catalytic oxidation of $\mathrm{CO}$ by $\mathrm{N}_{2} \mathrm{O}$ mediated by $\mathrm{AlVO}_{4}{ }^{+} / \mathrm{AlVO}_{3}{ }^{+}$ couple. The spin density distributions on individual atoms are shown in the isosurfaces, adapted from Ref. [42].

than that of $\mathrm{N}_{2} \mathrm{O}(\mathrm{N}-\mathrm{O}=1.74 \mathrm{eV})$, only a few gas-phase studies have examined catalytic $\mathrm{CO}$ oxidation with molecular $\mathrm{O}_{2}$ [34,47-54]. Four common oxygen species are involved in molecular $\mathrm{O}_{2}$ activation and dissociation: superoxide, peroxide, $\mathrm{O}^{-}$, and lattice oxygen [89]. Gas-phase studies have therefore almost always highlighted the negatively charged species because the net charge of anions tends to reduce and effectively activate molecular $\mathrm{O}_{2}$ to form highly reactive oxygen species [111]. Moreover, in the case of bare or homonuclear metal oxide clusters, more than one noble metal atom in these clusters, such as $\mathrm{Pt}_{n}{ }^{-}(n=3-6)$ [34], $\mathrm{Au}_{2}{ }^{-}$[48, 49], $\mathrm{Au}_{6}{ }^{-}$[47], and $\mathrm{Ag}_{n}{ }^{-}(n$ $=7,9,11$ ) $[50]$, may be vital in mediating the catalytic oxidation of $\mathrm{CO}$ by molecular $\mathrm{O}_{2}$.

Bare $\mathrm{Pt}_{n}{ }^{-}(n=3-6)$ cluster anions have been found to catalyze the oxidation of $\mathrm{CO}$ by $\mathrm{O}_{2}$ (Fig. 3(a)) [34]. The associated catalytic conversion is very effective, with an appreciable barrier $(<0.04 \mathrm{eV}, 300 \mathrm{~K})$, because of the small size of these clusters, meaning that each of the Pt atoms are exposed and coordinatively unsaturated. The mechanism for the sequential oxidation of $\mathrm{CO}$ by $\mathrm{Pt}_{4} \mathrm{O}_{2}{ }^{-}$presented in Fig. 3(b) suggests that $\mathrm{O}_{2}$ is
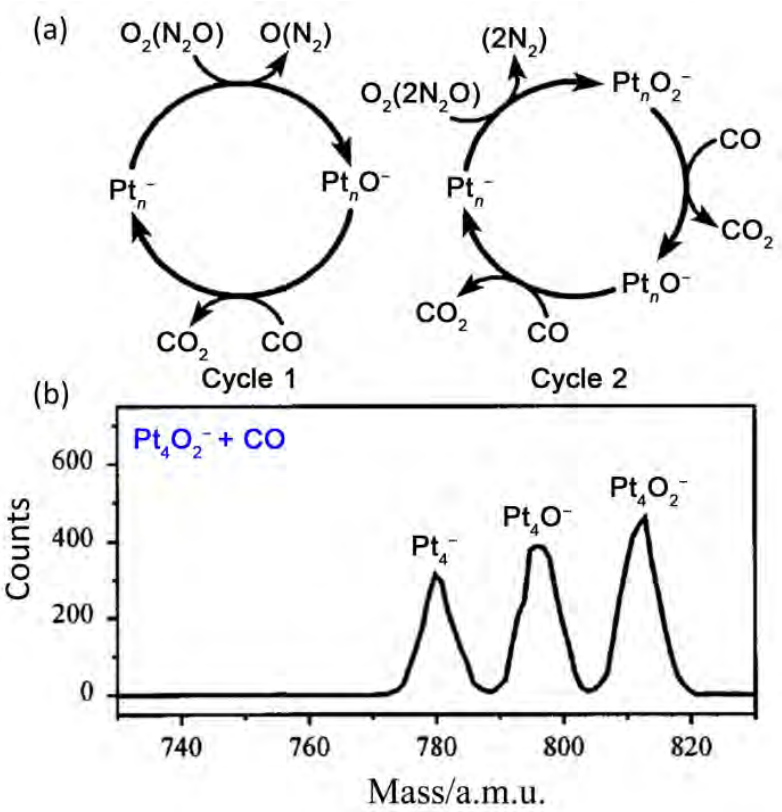

Fig. 3. (a) Catalytic cycles observed for the oxidation of $\mathrm{CO}$ to $\mathrm{CO}_{2}$ by $\mathrm{N}_{2} \mathrm{O}$ or $\mathrm{O}_{2}$ using $\mathrm{Pt}_{n}{ }^{-}$cluster anions. (b) Mass spectrum for the reaction $\mathrm{Pt}_{4} \mathrm{O}_{2}{ }^{-}+\mathrm{CO}$ at a collision energy of $0.05 \mathrm{eV}$ (adapted from Ref. [34]).

atomically adsorbed during this process, and the negative charge on the $\mathrm{Pt}_{n}{ }^{-}$cluster certainly plays an important role in the activation and dissociation of molecular $\mathrm{O}_{2}$. In contrast, the adsorption of molecular $\mathrm{O}_{2}$ on $\mathrm{Au}_{n}{ }^{-}$is significantly different. $\mathrm{O}_{2}$ is very sensitive to the number of gold atoms in $\mathrm{Au}_{n}{ }^{-}$clusters, such that clusters with even $n$ values are more likely to adsorb molecular $\mathrm{O}_{2}[47,49]$. The complete catalytic cycle for the oxidation of $\mathrm{CO}$ by $\mathrm{O}_{2}$ with catalysis by $\mathrm{Au}_{2}{ }^{-}$has been identified, both theoretically and experimentally $[48,49]$, as shown in Fig. 4. $\mathrm{Au}_{2} \mathrm{O}_{2}{ }^{-}$is the only product resulting from the interaction of $\mathrm{Au}_{2}{ }^{-}$with $\mathrm{O}_{2}$ (Fig. 4(a)). During the reaction of $\mathrm{CO}$ with a mixture of $\mathrm{Au}_{2}{ }^{-}$and $\mathrm{Au}_{2} \mathrm{O}_{2}{ }^{-}$(Fig. 4(b) and (c)), a relative loss of the signal owing to $\mathrm{Au}_{2} \mathrm{O}_{2}{ }^{-}$was observed, together with an increase in the $\mathrm{Au}_{2}{ }^{-}$signal, while there was no evidence for the formation of the atomic oxygen product $\mathrm{Au}_{2} \mathrm{O}^{-}$. These results strongly suggest that $\mathrm{O}_{2}$ may be adsorbed molecularly on $\mathrm{Au}_{2}^{-}$, followed by the generation of two $\mathrm{CO}_{2}$ molecules upon the reaction of $\mathrm{Au}_{2} \mathrm{O}_{2}{ }^{-}$with two $\mathrm{CO}$ molecules, as shown in Eq. (1). This proposed mechanism was subsequently confirmed by low

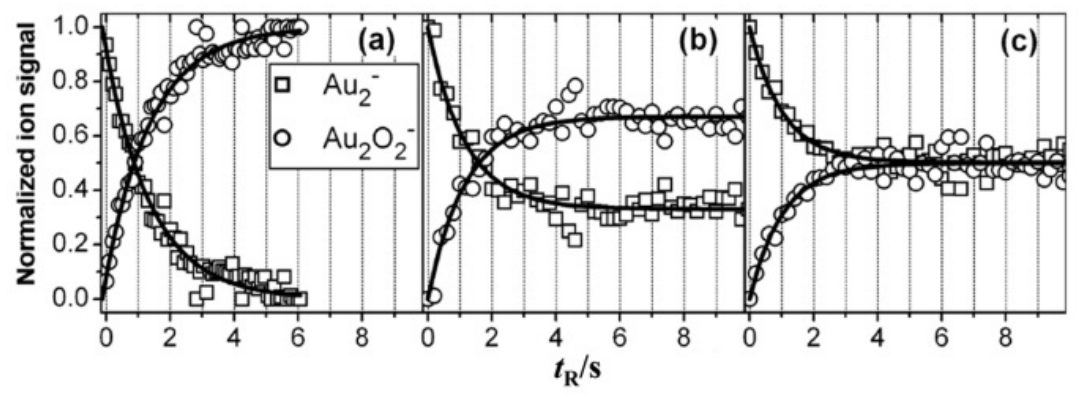

Fig. 4. Concentration of all product ions observed during the reactions of mass selected $\mathrm{Au}_{2}{ }^{-}$with $\mathrm{CO}$ and $\mathrm{O}_{2}$ inside the ion trap as a function of reaction time $\left(t_{\mathrm{R}}\right)$ for different $\mathrm{CO}$ partial pressures. (a) $p(\mathrm{CO})=0$ and $p\left(\mathrm{O}_{2}\right)=0.12 \mathrm{~Pa}$, (b) $p(\mathrm{CO})=p\left(\mathrm{O}_{2}\right)=0.12 \mathrm{~Pa}$, and $(\mathrm{c}) p(\mathrm{CO})=2 p\left(\mathrm{O}_{2}\right)=0.24 \mathrm{~Pa}$. The reaction temperature and bath gas $(\mathrm{He})$ pressure are $300 \mathrm{~K}$ and $1.2 \mathrm{~Pa}$, respectively, adapted from Ref. [49]. 
temperature (100-225 K) ion trap experiments in which the $\mathrm{Au}_{2}(\mathrm{CO}) \mathrm{O}_{2}{ }^{-}$intermediate was observed [49]. The detailed mechanism of this reaction has been determined through theoretical calculations $[48,49,112,113]$ and the most plausible process is presented in Fig. 5. The calculated pathway indicates the co-adsorption of $\mathrm{CO}$ and $\mathrm{O}_{2}$, either simultaneously or sequentially, and shows that these species do not compete for bonding sites but rather assist each other in the adsorption process [112]. This can be ascribed to the fact that the preadsorption of one reactant may affect the electronic structure of the $\mathrm{Au}_{2}{ }^{-}$, causing it to appear electronically different to the second approaching reactant.

$$
\mathrm{Au}_{2} \mathrm{O}_{2}^{-}+2 \mathrm{CO} \rightarrow \mathrm{Au}_{2}^{-}+2 \mathrm{CO}_{2}
$$

Recently, an ion trap study under multiple collision conditions found that the positively charged oxide cluster $\mathrm{Pd}_{6} \mathrm{O}_{4}{ }^{+}$was the catalytically active species in the low temperature oxidation of $\mathrm{CO}$ by $\mathrm{O}_{2}$ [52], as shown in Fig. $6(\mathrm{a}) \cdot \mathrm{Pd}_{6} \mathrm{O}_{4}{ }^{+}$was also found to be resistant to further oxidation over a large temperature range. During the interaction of $\mathrm{Pd}_{6} \mathrm{O}_{4}{ }^{+}$with an $\mathrm{O}_{2} / \mathrm{CO}$ mixture (Fig. 6(b)), various products were identified, including $\mathrm{Pd}_{6} \mathrm{O}_{3}{ }^{+}$, $\mathrm{Pd}_{6} \mathrm{O}_{5}{ }^{+}$and $\mathrm{Pd}_{6} \mathrm{O}_{5} \mathrm{CO}^{+}$. These results indicate the reaction of $\mathrm{Pd}_{6} \mathrm{O}_{4}{ }^{+}$with $\mathrm{CO}$ leading to a loss of oxygen atoms, as demonstrated by the detection of clusters containing odd numbers of oxygen atoms (such as $\mathrm{Pd}_{6} \mathrm{O}_{5}{ }^{+}$) [52]. The calculated pathways and the catalytic cycle demonstrate effective $\mathrm{CO}$ oxidation by molecular $\mathrm{O}_{2}$, catalyzed by the palladium hexamer at room temperature. However, it is clear that $\mathrm{Pd}_{6}{ }^{+}$is not part of the catalytic cycle. Instead, the $\mathrm{Pd}_{6} \mathrm{O}_{4}{ }^{+}$oxide cluster has been identified as the catalytically active species. This is in contrast to the oxidation of $\mathrm{CO}$ by $\mathrm{Pt}_{n}{ }^{ \pm}$and $\mathrm{Au}_{n}{ }^{ \pm}$clusters, in which these clusters are part of the catalytic cycles. Density functional theory (DFT) calculations are in good agreement with these experimental results and provide molecular-level insights into Pd catalysis.

The above publications show that more than one noble metal atom may indeed be vital to the catalytic cycle during $\mathrm{CO}$ oxidation by molecular $\mathrm{O}_{2}$, because clusters with a single noble atom, such as the $\mathrm{AuO}_{2}{ }^{-}$anion, appear unable to catalyze such

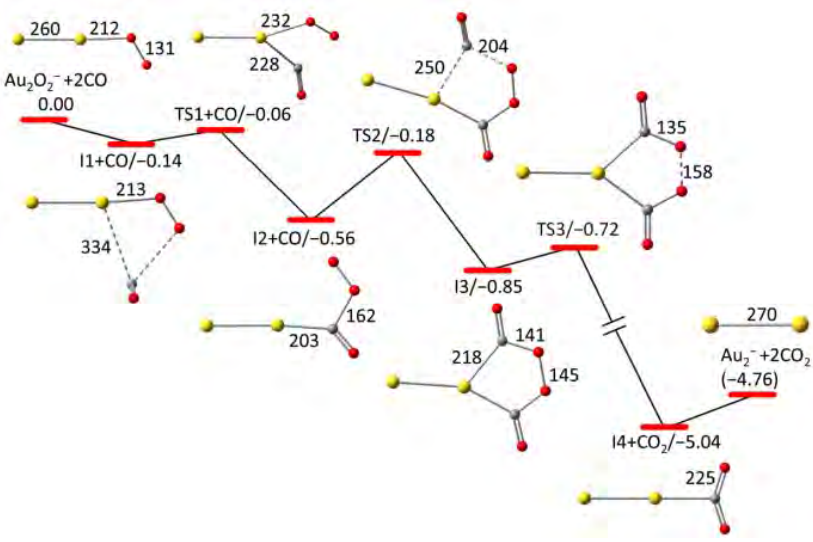

Fig. 5. DFT calculated reaction pathway for catalytic cycle $\mathrm{Au}_{2} \mathrm{O}_{2}{ }^{-}+2 \mathrm{CO}$ $\rightarrow \mathrm{Au}_{2}{ }^{-}+2 \mathrm{CO}_{2}$. The zero-point vibration corrected energies $\left(\Delta H_{0 K} / \mathrm{eV}\right)$ of reaction intermediates (I1-I4), transition states (TS1-TS3), and products $\left(\mathrm{Au}_{2}{ }^{-}+2 \mathrm{CO}_{2}\right)$ with respect to the separated reactant $\left(\mathrm{Au}_{2} \mathrm{O}_{2}{ }^{-}+\right.$ $2 \mathrm{CO})$ are given. Bond lengths are given in pm, adapted from Refs. $[13,48,53,112,113]$. (a)

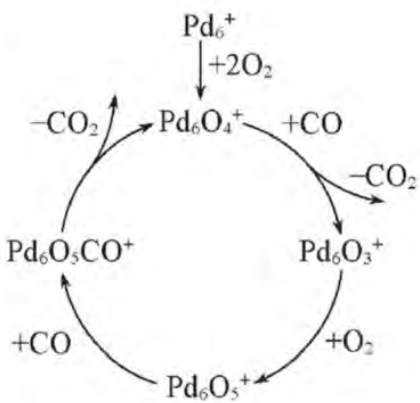

(b)

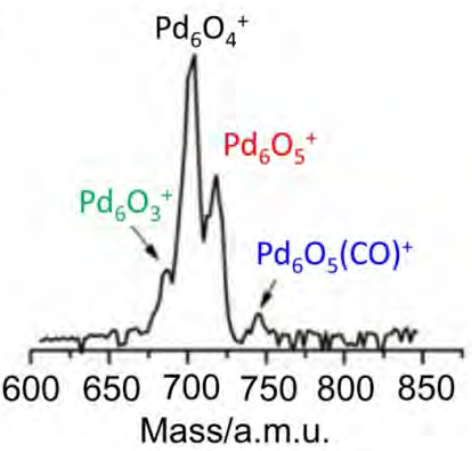

Fig. 6. (a) Proposed catalytic reaction cycle on the basis of experimental and computational studies. (b) Representative ion mass distribution obtained after a reaction time of $0.1 \mathrm{~s}$ of the reaction between $\mathrm{Pd}_{6}{ }^{+}$and $\mathrm{O}_{2} / \mathrm{CO}\left(p\left(\mathrm{O}_{2}\right)=0.09 \mathrm{~Pa} ; p(\mathrm{CO})=0.01 \mathrm{~Pa} ; p(\mathrm{He})=0.9 \mathrm{~Pa}\right)$ recorded at $300 \mathrm{~K}$, adapted from Ref. [52].

cycles [35]. Despite this, developing catalysts with well-defined and atomically distributed single metal centers, namely single-atom catalysts, is of great importance with regard to improving the activity and selectivity of particular chemical processes [114]. Single-atom catalysts that make the most effective use of active metal atoms have exhibited unexpected catalytic properties in a large number of reactions [29,30,115]. Cluster-confined single-atom catalysts, as presented in Fig. 7, may serve as an ideal model to explore the mechanistic details of the unique catalytic activity of supported single metal atoms at the strictly molecular level.

Recently, for the first time, a very effective catalytic process for $\mathrm{CO}$ oxidation by molecular $\mathrm{O}_{2}$ promoted by a single gold atom confined on an aluminum oxide cluster, $\mathrm{AuAl}_{3} \mathrm{O}_{3-5}{ }^{+}$, was identified in an ion trap reactor under mild conditions [53]. Heteronuclear oxide clusters containing gold are of significant

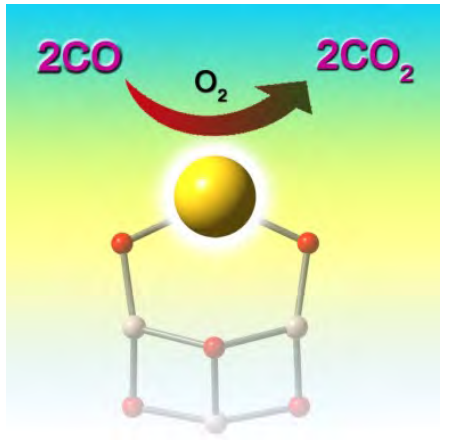

Fig. 7. A schematic picture for cluster confined single atom catalyst in the catalytic oxidation of $\mathrm{CO}$ by molecular $\mathrm{O}_{2}$. 
importance in our quest to understand the catalytic nature of supported gold, which has been shown to exhibit exceptional activity in low-temperature CO oxidation [116-118]. Fig. 8(f) demonstrates that $\mathrm{AuAl}_{3} \mathrm{O}_{5}{ }^{+}$is capable of oxidizing two $\mathrm{CO}$ molecules consecutively to form $\mathrm{AuAl}_{3} \mathrm{O}_{4}{ }^{+}$followed by $\mathrm{AuAl}_{3} \mathrm{O}_{3}{ }^{+}$, the latter of which can react with a single $\mathrm{O}_{2}$ molecule to regenerate $\mathrm{AuAl}_{3} \mathrm{O}_{5}{ }^{+}$(Fig. 8(g)). Furthermore, $\mathrm{AuAl}_{3}{ }^{16} \mathrm{O}_{3}{ }^{+}$has been shown to interact with a mixture of $\mathrm{C}^{16} \mathrm{O}$ and ${ }^{18} \mathrm{O}_{2}$ to produce the fully substituted ${ }^{18} \mathrm{O}$ species $\mathrm{AuAl}_{3}{ }^{18} \mathrm{O}_{3-5}{ }^{+}$. This result clearly identifies a catalytic cycle for $\mathrm{CO}$ oxidation by $\mathrm{O}_{2}$. Quantum chemistry calculations have been employed to study the mechanism of $\mathrm{CO}$ oxidation catalyzed by $\mathrm{AuAl}_{3}{ }^{18} \mathrm{O}_{3-5}{ }^{+}$clusters, and the calculated pathways are presented in Fig. 9. The lowest energy structures of $\mathrm{AuAl}_{3} \mathrm{O}_{3-5}{ }^{+}$have a doublet spin multiplicity. $\mathrm{AuAl}_{3} \mathrm{O}_{5}{ }^{+}$can transfer two $\mathrm{O}$ atoms, consecutively, to oxidize two $\mathrm{CO}$ molecules while forming the reductive product $\mathrm{AuAl}_{3} \mathrm{O}_{3}{ }^{+}$. The spin density of this species is primarily situated on an $\mathrm{Al}$ atom capable of adsorbing an $\mathrm{O}_{2}$ molecule and regenerating $\mathrm{AuAl}_{3} \mathrm{O}_{5}{ }^{+}$, thus completing the catalytic cycle. Each of the predicted intermediates and transition states is lower in energy than the corresponding reactant. Thus, these calculations both support and explain the experimental observations very well [53].

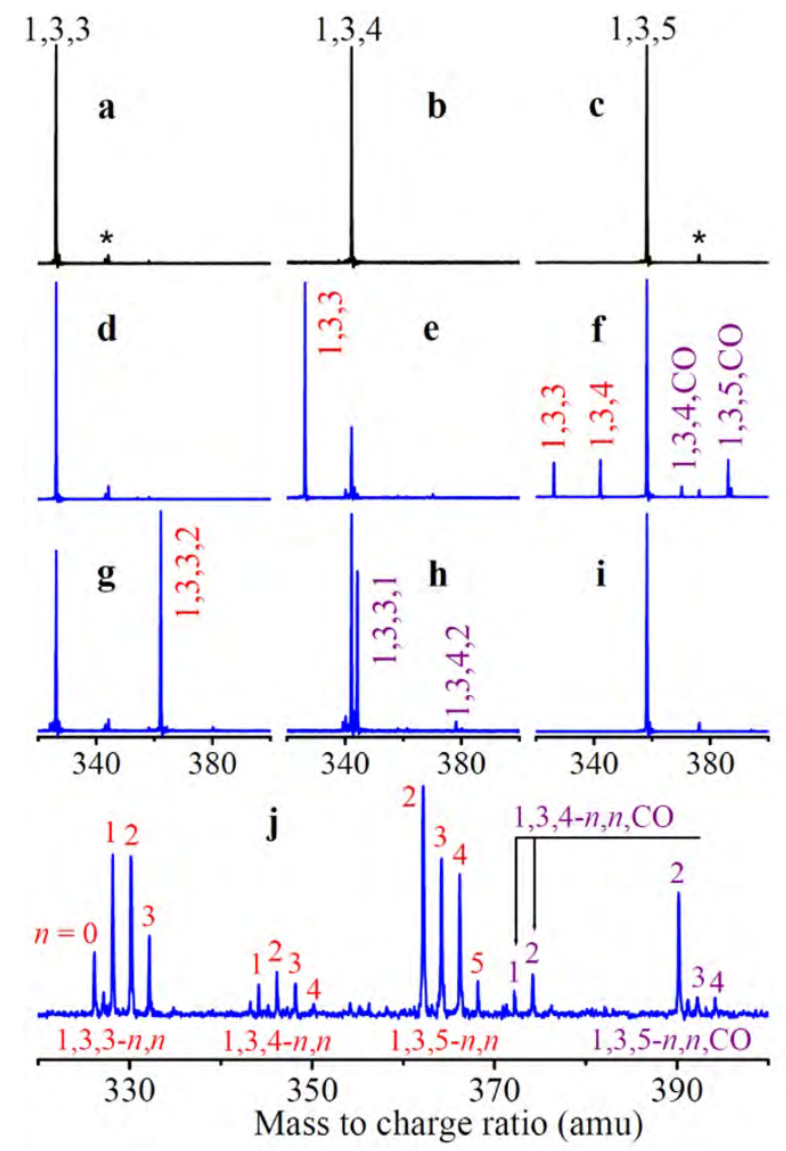

Fig. 8. Elementary and catalytic reactions of $\mathrm{AuAl}_{3} \mathrm{O}_{3-5}{ }^{+}$clusters mediated $\mathrm{CO}$ oxidation by molecular $\mathrm{O}_{2}$. The time periods for all of the reactions are $1.0 \mathrm{~ms}$. The $\mathrm{Au}_{x} \mathrm{Al}_{y}{ }^{16} \mathrm{O}_{z}{ }^{+}$and $\mathrm{Au}_{x} \mathrm{Al}_{y}{ }^{16} \mathrm{O}_{z} \mathrm{CO}^{+}$species are labeled as $x, y, z$ and $x, y, z, \mathrm{CO}$, respectively. Similarly, the $\mathrm{Au}_{x} \mathrm{Al}_{y}{ }^{16} \mathrm{O}_{z-n}{ }^{18} \mathrm{O}_{n}{ }^{+}(n \neq 0$ is labeled as $x, y, z-n, n$ and the $\mathrm{Au}_{x} \mathrm{Al}_{y}{ }^{16} \mathrm{O}_{z-n}{ }^{18} \mathrm{O}_{n} \mathrm{CO}^{+}$is labeled as $x, y, z-n, n$ CO, adapted from Ref. [53].

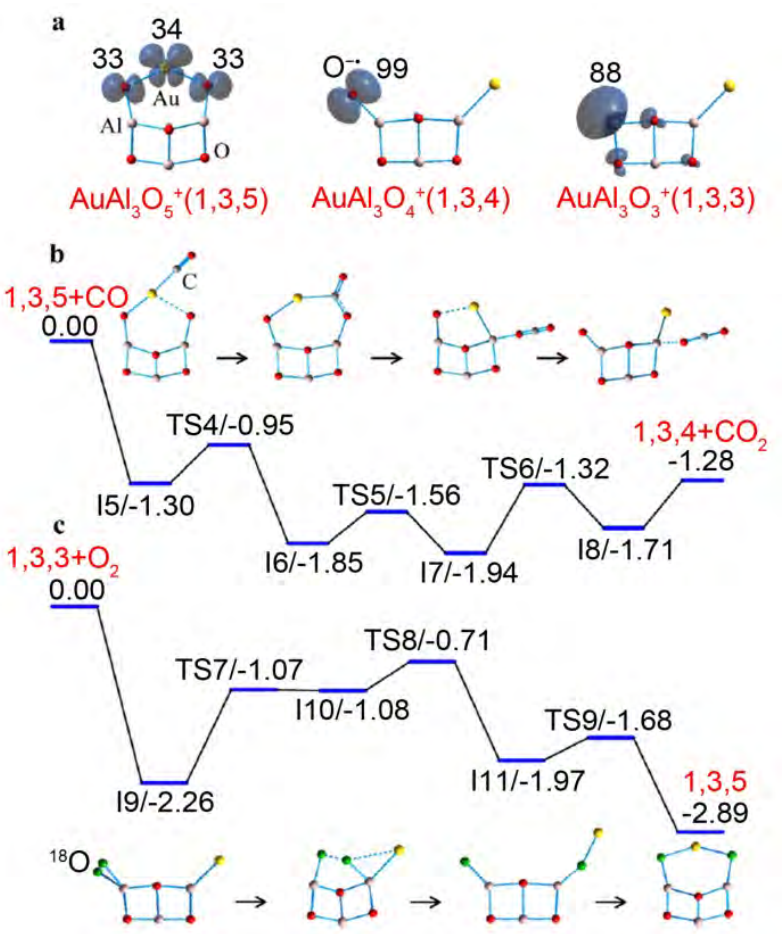

Fig. 9. (a) DFT calculated structures for $\mathrm{AuAl}_{3} \mathrm{O}_{3-5}{ }^{+}$clusters and (b, c) the reaction mechanisms of elementary steps, adapted from Ref. [53].

The key to the catalytic activity of $\mathrm{AuAl}_{3} \mathrm{O}_{4}{ }^{+}$is its unique structure, in which both a reductive $\mathrm{Au}-\mathrm{Al}$ bond and a highly oxidative $\mathrm{O}^{-\bullet}$ radical center are found (Fig. 9(a)). These bonding features result from relativistic effects that produce the significant $\mathrm{Au}-\mathrm{Al}$ bond strength in $\mathrm{AuAl}_{3} \mathrm{O}_{4}{ }^{+}$and are also responsible for the change in the charge of the gold atom during the catalytic cycle. In contrast, the relatively weak $\mathrm{Ag}-\mathrm{Al}$ bond allows the formation of the $\mathrm{Ag}-\mathrm{O}$ bond in the $\mathrm{AgAl}_{3} \mathrm{O}_{4}{ }^{+}$cluster, which does not contain a highly oxidative radical oxygen atom and thus cannot promote the catalytic oxidation of CO by molecular $\mathrm{O}_{2}$ [53]. The theoretical catalytic cycle is shown in Fig. 10 together with the change in the charge on the gold atoms throughout the cycle. This rather effective catalytic process is driven by electron cycling, primarily through the making and breaking of an $\mathrm{Au}-\mathrm{Al}$ bond [53]. This Au-Al-O system represents the first identification of catalytic $\mathrm{CO}$ oxidation by molecular $\mathrm{O}_{2}$ mediated by a cluster-confined single gold atom, and thus serves as an important step in understanding noble metal catalysis at the strictly molecular level. Furthermore, this gas-phase catalysis parallels the mechanism of CO oxidation in condensed phase systems employing the dual catalytic sites on an $\mathrm{Au} / \mathrm{TiO}_{2}$ catalyst [118], in which the delivery and oxidation of $\mathrm{CO}$ occurs at both oxide $\left(\mathrm{TiO}_{2}\right)$ and gold atom sites. Mass spectrometric analyses in conjunction with quantum chemistry calculations allow the systematic exploration of the factors that govern the reactivity of each of the steps during catalytic CO oxidation. In this manner, the polarity conversion of gold atoms from positive to negative has been identified as indispensable to the promotion of the catalytic cycle. The mechanistic details of each elementary step of a catalytic cycle and the experimentally controversial issues, such as the oxidation state of gold 


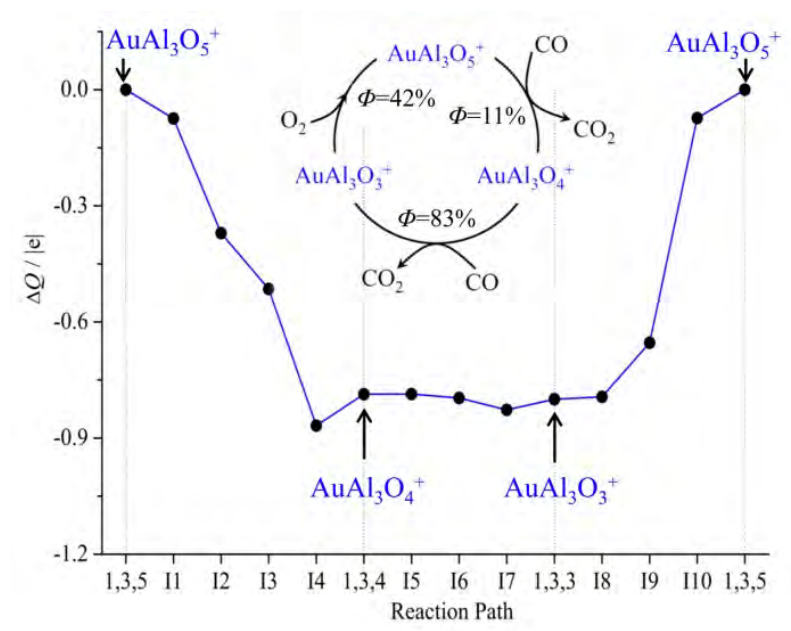

Fig. 10. Identified catalytic cycle together with the reaction efficiencies in elementary steps. Charge cycling on the gold atoms during the catalytic cycle are given on the basis of natural bond orbital analysis, adapted from Ref. [53].

and the importance of the interface between gold catalysts and oxide supports, cannot be determined solely from condensed phase studies.

Very recently, another catalytic cycle for $\mathrm{CO}$ oxidation by molecular $\mathrm{O}_{2}$ mediated by single Pt atoms confined on aluminum cluster anions $\left(\mathrm{PtAl}_{3} \mathrm{O}_{7}^{-}, \mathrm{PtAl}_{3} \mathrm{O}_{6}{ }^{-}\right.$or $\left.\mathrm{PtAl}_{3} \mathrm{O}_{5}{ }^{-}\right)$has been reported [54]. Similar to the cycle catalyzed by $\mathrm{AuAl}_{3} \mathrm{O}_{3-5^{+}}$, this study found that the reductive $\mathrm{Pt}$ center in $\mathrm{PtAl}_{3} \mathrm{O}_{6}{ }^{-}$can also coexist with $\mathrm{O}^{-}$(Fig. 11(a)). Thus, after the oxidation of the first $\mathrm{CO}$ molecule by $\mathrm{PtAl}_{3} \mathrm{O}_{7}{ }^{-}$, the resulting $\mathrm{PtAl}_{3} \mathrm{O}_{6}{ }^{-}$can also oxidize a second $\mathrm{CO}$ molecule. In contrast, upon substituting the $\mathrm{Pt}$ atom in $\mathrm{PtAl}_{3} \mathrm{O}_{7}^{-}$with an $\mathrm{Al}$ atom, the purely aluminum-based oxide cluster $\mathrm{Al}_{4} \mathrm{O}_{7}^{-}$is able to oxidize a single $\mathrm{CO}$ molecule. Because this step gives rise to the inert species $\mathrm{Al}_{4} \mathrm{O}_{6}{ }^{-}$, the $\mathrm{CO}$ oxidation process is terminated. This can be explained by the proposed Electronegativity-Ladder (E-Ladder) effect (Fig. 11(b)). This effect originates from the position of the electronegativity of Pt atoms (2.28) situated between those of $\mathrm{Al}$ (1.61) and $\mathrm{O}$ (3.44). The E-Ladder phenomenon promotes the generation of $\mathrm{O}^{-}$, which gives $\mathrm{PtAl}_{3} \mathrm{O}_{6}{ }^{-}$the ability to oxidize

$$
\text { (a) }
$$
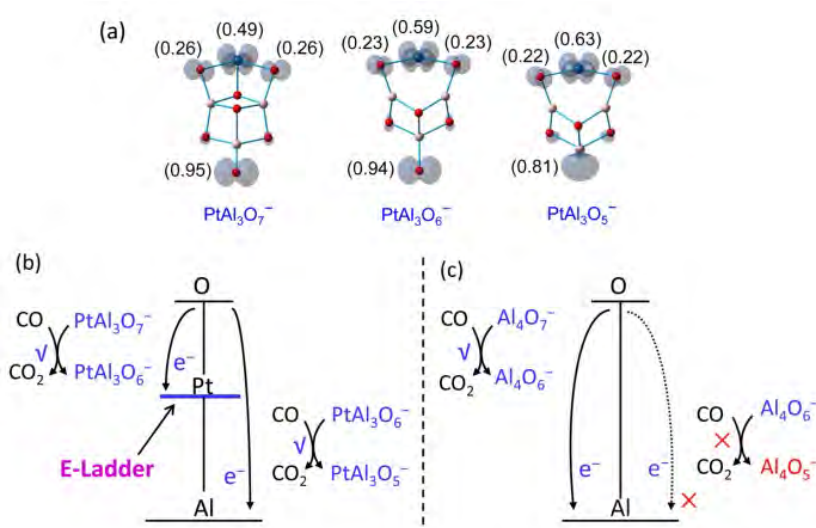

Fig. 11. (a) DFT calculated lowest energy structures of $\mathrm{PtAl}_{3} \mathrm{O}_{7}^{-}$, $\mathrm{PtAl}_{3} \mathrm{O}_{6}{ }^{-}$, and $\mathrm{PtAl}_{3} \mathrm{O}_{5}{ }^{-}$. The schematic drawing of the consecutive oxidation of two $\mathrm{CO}$ molecules by atomic clusters with (b) and without (c) E-Ladder, adapted from Ref. [54].
CO. Thus, the large enthalpy value associated with the catalytic oxidation of $\mathrm{CO}$ by molecular $\mathrm{O}_{2}\left(2 \mathrm{CO}+\mathrm{O}_{2} \rightarrow 2 \mathrm{CO}_{2}, \Delta \mathrm{H}_{0 \mathrm{~K}}=\right.$ $\sim 5.90 \mathrm{eV}$ ) can be distributed much more evenly over several elementary steps in the Pt-Al-O system, representing an improvement over the pure Al-O system [54]. It should be noted that the electronegativity values of most noble metal atoms (2.20-2.54) [119] are intermediate between those of non-noble metal atoms and oxygen. Thus, the E-Ladder effect as observed in the case of the Pt-Al-O system should extend to other noble metal-doped oxide clusters. A newly reported result also demonstrates that single $\mathrm{Rh}$ atoms confined on aluminum oxide clusters, $\mathrm{RhAl}_{2} \mathrm{O}_{6}{ }^{+}$, can oxidize five $\mathrm{CO}$ molecules consecutively, simultaneously generating the oxygen deficient product $\mathrm{RhAl}_{2} \mathrm{O}^{+}$[16]. This represents a significant improvement in the field of cluster science, considering that the transfer of at most two oxygen atoms from cluster-confined single noble metal atoms is more commonly observed. In future, it is therefore possible that catalytic $\mathrm{CO}$ oxidation by molecular $\mathrm{O}_{2}$ mediated with cluster-confined $\mathrm{Rh}$ atoms will be performed.

\section{Catalytic functionalization of methane}

The conversion of $\mathrm{CH}_{4}$ from biogenic or fossil resources to value-added feedstocks is currently a central challenge related to solving global energy issues. However, at present there are no large-scale processes that are both economically feasible and environmentally benign for the conversion of methane to products such as methanol $[120,121]$ under ambient conditions. This shortcoming is primarily owing to the molecular properties of $\mathrm{CH}_{4}$, which has no permanent dipole moment, rather low polarizability, a high ionization energy, and a negative electron affinity. In addition, a significant energy input is required for both the homo- and heterolytic cleavage of any of the $\mathrm{C}-\mathrm{H}$ bonds in this molecule. Thus, the transformation of $\mathrm{CH}_{4}$ has been regarded as a much sought-after achievement in the chemical community [122-124]. Great efforts have been made to determine the elementary steps and mechanistic details involved with $\mathrm{CH}_{4}$ conversion, and some important gas-phase results have been published [13,14,17-19,26,125]. However, despite extensive studies regarding $\mathrm{CH}_{4}$ activation and conversion, the associated catalytic cycles have been reported much less frequently, as can be seen from Table 1 .

The $\mathrm{Pt}^{+}$-catalyzed oxidation of $\mathrm{CH}_{4}$ by $\mathrm{O}_{2}$ leads to the production of $\mathrm{CH}_{2} \mathrm{O}$ and $\mathrm{CH}_{3} \mathrm{OH}$ (Fig. 12). In step 1 of this process, the highly selective dehydrogenation of $\mathrm{CH}_{4}$ generates $\mathrm{PtCH}_{2}{ }^{+}$ [57], which serves as an important intermediate in the subsequent $\mathrm{CH}_{4}$ conversion process. $\mathrm{PtCH}_{2}{ }^{+}$can react with molecular $\mathrm{O}_{2}$ to form $\mathrm{Pt}^{+}$and $\mathrm{CH}_{2} \mathrm{O}_{2}$ (70\% yield, step 2) as well as the monoxide $\mathrm{PtO}^{+}$and $\mathrm{CH}_{2} \mathrm{O}$ (30\%, step 3). This $\mathrm{PtO}^{+}$intermediate can also contribute to the catalytic cycle, since it is transitioned back to $\mathrm{Pt}^{+}$along with the formation of $\mathrm{CH}_{3} \mathrm{OH}$ as a result of the reaction with $\mathrm{CH}_{4}$ (step 4). The key to this overall cycle is the reaction between $\mathrm{PtCH}_{2}{ }^{+}$and $\mathrm{O}_{2}$ [126], which is not selective and yields a mixture of formic acid and various decomposition products. In addition to promoting the reaction with molecular $\mathrm{O}_{2}, \mathrm{PtCH}_{2}{ }^{+}$can also catalyze the conversion of $\mathrm{CH}_{4}$ to $\mathrm{CO}$ in a sequence of dehydrogenation steps via a gas-phase water-gas 


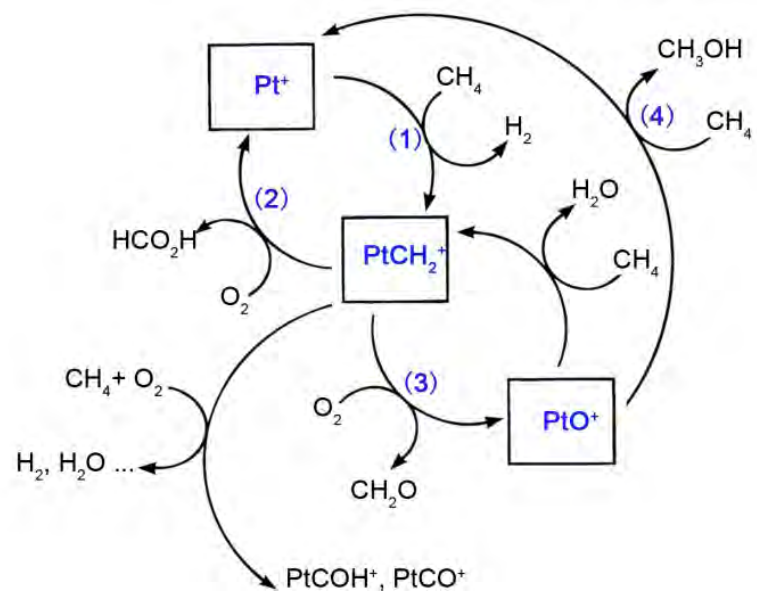

Fig. 12. The proposed $\mathrm{Pt}^{+}$-catalyzed oxidation of methane by molecular $\mathrm{O}_{2}$ in the gas phase, adapted from Ref. [57].

reaction, to generate $\mathrm{CO}$ and $\mathrm{H}_{2} \mathrm{O}$ [59]. Once the final intermediate, $\left(\mathrm{H}_{2} \mathrm{O}\right) \mathrm{Pt}(\mathrm{CO})^{+}$, is formed, approximately $4.42 \mathrm{eV}$ is required to release the $\mathrm{H}_{2} \mathrm{O}$ and $\mathrm{CO}$ ligands. This mechanism resembles heterogeneous catalysis in which the release of the product from the catalytic center and the regeneration of the catalysts are achieved by heating.

Temperature-tuning ion trap experiments have discovered two $\mathrm{CH}_{4}$ oxidation pathways that lead to the formation of either $\mathrm{CH}_{2} \mathrm{O}$ or $\mathrm{C}_{2} \mathrm{H}_{4}$ [62], as shown in Fig. 13. Using this process, a mixture of $\mathrm{CH}_{4}$ and molecular $\mathrm{O}_{2}$ can be selectively converted to $\mathrm{CH}_{2} \mathrm{O}$ at temperature below $250 \mathrm{~K}$ (cycle I). However, at higher temperatures, $\mathrm{O}_{2}$ does not readily adsorb on the $\mathrm{Au}_{2}{ }^{+}$dimer, and the catalyzed cooperative dehydrogenation of $\mathrm{CH}_{4}$ results in the formation of $\mathrm{C}_{2} \mathrm{H}_{4}$. This observation is consistent with other results showing that the $\mathrm{Au}_{2}{ }^{+}$dimer readily activates methane to facilitate dehydrogenation, eventually leading to the selective formation of ethylene at room temperature $[61,63]$. In the case of cycle I (Fig. 13), DFT calculations have indicated that only $\mathrm{Au}_{2}\left(\mathrm{C}_{2} \mathrm{H}_{4}\right)_{2}{ }^{+}$is able to react with $\mathrm{O}_{2}$, and that the binding energy of $\mathrm{O}_{2}$ on $\mathrm{Au}_{2}\left(\mathrm{CH}_{4}\right)_{2} \mathrm{O}_{2}{ }^{+}$is only $0.47 \mathrm{eV}$. Subsequent to this step, $\mathrm{Au}_{2}\left(\mathrm{CH}_{4}\right)_{2} \mathrm{O}_{2}{ }^{+}$reacts with a second $\mathrm{O}_{2}$ and a third $\mathrm{CH}_{4}$ to form $\mathrm{Au}_{2}\left(\mathrm{C}_{3} \mathrm{H}_{8} \mathrm{O}_{2}\right)^{+}$. The final step involves the loss of two $\mathrm{CH}_{2} \mathrm{O}$ molecules from $\mathrm{Au}_{2}\left(\mathrm{C}_{3} \mathrm{H}_{8} \mathrm{O}_{2}\right)^{+}$to regenerate

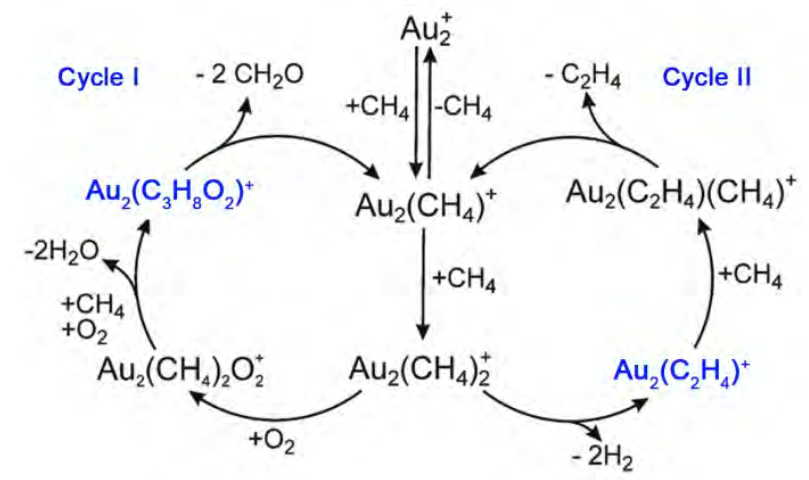

Fig. 13. Competing catalytic cycles for oxidation of $\mathrm{CH}_{4}$ catalyzed by $\mathrm{Au}_{2}{ }^{+}$: Cycle I involves oxidation of $\mathrm{CH}_{4}$ to $\mathrm{CH}_{2} \mathrm{O}(<250 \mathrm{~K})$; Cycle II involves dehydrocoupling of $\mathrm{CH}_{4}$ to yield $\mathrm{C}_{2} \mathrm{H}_{4}$, adapted from Refs. [61-63].
$\mathrm{Au}_{2}\left(\mathrm{CH}_{4}\right)^{+}$. In cycle II, the direct desorption of $\mathrm{C}_{2} \mathrm{H}_{4}$ from $\mathrm{Au}_{2}\left(\mathrm{C}_{2} \mathrm{H}_{4}\right)^{+}$was determined to be hindered. Instead, the cycle proceeds via an intermediate formed by the initial adsorption of a $\mathrm{CH}_{4}$ molecule on $\mathrm{Au}_{2}\left(\mathrm{C}_{2} \mathrm{H}_{4}\right)\left(\mathrm{CH}_{4}\right)^{+}$, with the subsequent desorption of $\mathrm{C}_{2} \mathrm{H}_{4}$.

If the $\mathrm{CH}_{4}$ conversion reactions observed on a laboratory scale can be extended to large-scale industrial processes, $\mathrm{CH}_{4}$ resources could be used much more efficiently. However, although single $\mathrm{Pt}^{+}$ions $[57,59,126]$ or $\mathrm{Au}_{2}{ }^{+}$dimers [61-63] can promote the catalytic conversion of $\mathrm{CH}_{4}$ into various products, such as $\mathrm{CH}_{2} \mathrm{O}, \mathrm{CH}_{3} \mathrm{OH}$, and $\mathrm{C}_{2} \mathrm{H}_{4}$, the overall process is highly complex and exhibits low selectivity. In contrast, single Pt atoms confined on aluminum oxide cluster anions, $\mathrm{PtAl}_{2} \mathrm{O}_{4}{ }^{-}$, can activate $\mathrm{CH}_{4}$ to generate neutral $\mathrm{CH}_{2} \mathrm{O}$ as the sole product [127]. In addition, single $\mathrm{Rh}$ atoms confined on aluminum oxide cluster cations, $\mathrm{RhAl}_{3} \mathrm{O}_{4}{ }^{+}$, can promote the conversion of $\mathrm{CH}_{4}$ to syngas ( $\mathrm{CO}$ and $\mathrm{H}_{2}$ ) [17]. Therefore, in future, it will be important to expend significant effort investigating both direct and indirect $\mathrm{CH}_{4}$ conversions mediated with cluster-confined single active atoms.

\section{Catalytic decarboxylation}

The decarboxylation reaction $[27,28]$ is a highly useful means of producing active organometallic species, and continues to attract considerable interest as an inexpensive and environmentally benign technique in various syntheses, such as the selective decomposition of acids [128] and the $\mathrm{C}-\mathrm{C}$ coupling of esters $[28,129]$. In this section, we briefly discuss two catalytic decarboxylation cycles mediated by metals: the metal-dependent decompositions of $\mathrm{CH}_{3} \mathrm{COOH}[64,65]$ (Fig. 14) and $\mathrm{HCOOH}[67,130]$, and the $\mathrm{C}-\mathrm{C}$ coupling of $\mathrm{C}_{3} \mathrm{H}_{5} \mathrm{O}_{2} \mathrm{CCH}_{3}$ mediated by coinage metal complexes [68,69] (Fig. 15).

The thermal decomposition of $\mathrm{CH}_{3} \mathrm{COOH}$ can proceed via two competing pathways without the participation of a metal catalyst, generating (1) $\mathrm{CH}_{2} \mathrm{CO}$ and $\mathrm{H}_{2} \mathrm{O}$ (Eq. (2)) or (2) $\mathrm{CH}_{4}$ and $\mathrm{CO}_{2}$ (Eq. (3)), with the former being much more favorable. Multistate spectrometry has provided insights into the key reactions and intermediates in the associated condensed phase catalytic processes $[64,65,68,69]$. The 0'Hair group uncovered two different types of metal catalysts that can induce the selective decomposition of $\mathrm{CH}_{3} \mathrm{COOH}$ via dehydration (Eq. (2)) or

(a)

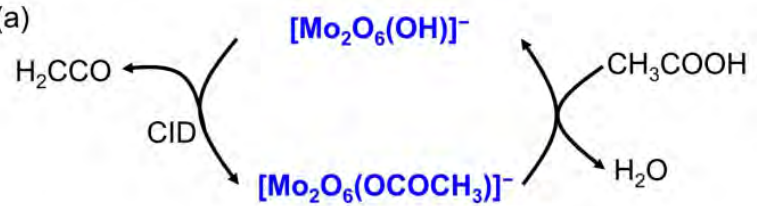

(b)

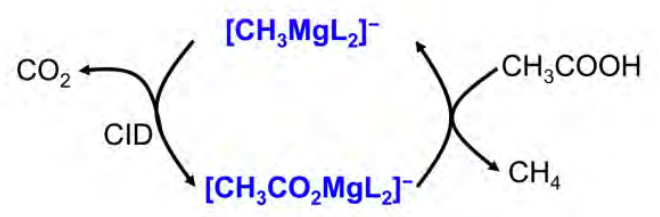

Fig. 14. Gas-phase catalytic cycle for (a) the dehydration of $\mathrm{CH}_{3} \mathrm{COOH}$ and (b) the decarboxylation of $\mathrm{CH}_{3} \mathrm{COOH}$, adapted from Refs. $[64,65]$. 


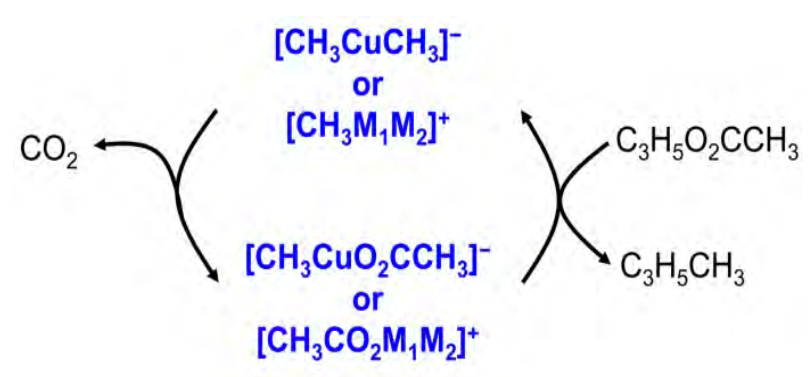

Fig. 15. Decarboxylative $C-C$ bond coupling of allylacetate catalyzed by $\left[\mathrm{CH}_{3} \mathrm{CuCH}_{3}\right]^{-}$anion or by coinage metal organometallic cluster cations $\left[\mathrm{CH}_{3} \mathrm{M}_{1} \mathrm{M}_{2}\right]^{+}(\mathrm{M}=\mathrm{Cu}, \mathrm{Ag})$, adapted from Refs. [68,69].

decarboxylation (Eq. (3)). The dehydration of $\mathrm{CH}_{3} \mathrm{COOH}$ to produce $\mathrm{CH}_{2} \mathrm{CO}$ and $\mathrm{H}_{2} \mathrm{O}$ can be catalyzed by binuclear $\left(\left[\mathrm{M}_{2} \mathrm{O}_{6}(\mathrm{OH})\right]^{-}\right.$, Fig. $\left.14(\mathrm{a})\right)$ or mononuclear $\left(\left[\mathrm{MO}_{3}(\mathrm{OH})\right]^{-}\right)$anions, where $\mathrm{M}=\mathrm{Mo}$ and $\mathrm{W}$, while $\left[\mathrm{Cr}_{2} \mathrm{O}_{6}(\mathrm{OH})\right]^{-}$and $\left[\mathrm{CrO}_{3}(\mathrm{OH})\right]^{-}$do not promote the reaction [64]. During the dehydration process (Fig. 14(a)), the first step involves the combination of the metal anion with $\mathrm{CH}_{3} \mathrm{COOH}$ to yield an acetate complex, $\left[\mathrm{Mo}_{2} \mathrm{O}_{6}\left(\mathrm{OCOCH}_{3}\right)\right]^{-}$. The second step is the elimination of $\mathrm{CH}_{2} \mathrm{CO}$ in response to collisional activation to reform $\left[\mathrm{Mo}_{2} \mathrm{O}_{6}(\mathrm{OH})\right]^{-}$, representing the rate-determining step. These gas-phase studies mirror the catalytic processes that occur in the condensed phase, in which the decomposition of $\mathrm{CH}_{3} \mathrm{COOH}$ at high temperatures is required to induce $\mathrm{CH}_{2} \mathrm{CO}$ loss with regeneration of surface hydroxyl sites [131].

$$
\begin{gathered}
\mathrm{CH}_{3} \mathrm{COOH} \rightarrow \mathrm{CH}_{2} \mathrm{CO}+\mathrm{H}_{2} \mathrm{O} \\
\mathrm{CH}_{3} \mathrm{COOH} \rightarrow \mathrm{CH}_{4}+\mathrm{CO}_{2}
\end{gathered}
$$

Fig. 14(b) shows the two-step catalytic cycle for the decarboxylation of $\mathrm{CH}_{3} \mathrm{COOH}$ mediated by $\left[\mathrm{CH}_{3} \mathrm{MgL}_{2}\right]^{-}[\mathrm{L}=\mathrm{Cl}$, $\mathrm{O}_{2} \mathrm{CCH}_{3}$ ] species [65]. The first step involves the addition of $\mathrm{CH}_{3} \mathrm{COOH}$ together with the elimination of $\mathrm{CH}_{4}$ to yield $\left[\mathrm{CH}_{3} \mathrm{CO}_{2} \mathrm{MgL}_{2}\right]^{-}$. The second step is decarboxylation in response to collisional activation to yield $\left[\mathrm{CH}_{3} \mathrm{MgL}_{2}\right]^{-}$species. Gas-phase decarboxylation reactions are closely related to the proto-decarboxylation of carboxylic acids mediated by metal salts in the condensed phase [132]. A similar cycle mediated by $\left.\mathrm{HMgL}_{2}\right]^{-}$has also been demonstrated to occur in the catalytic decomposition of $\mathrm{HCOOH}$ to produce $\mathrm{H}_{2}$ and $\mathrm{CO}_{2}$ [66].

$$
\begin{aligned}
\mathrm{HCOOH} & \rightarrow \mathrm{H}_{2} \mathrm{O}+\mathrm{CO} \\
\mathrm{HCOOH} & \rightarrow \mathrm{H}_{2}+\mathrm{CO}_{2}
\end{aligned}
$$

The selective catalytic decomposition of $\mathrm{HCOOH}$ has potentially important applications, such as in the field of hydrogen storage $[133,134]$. In the absence of a catalyst, gas-phase results [128] indicate that the dehydration pathway (Eq. (4)) is more favorable than decarboxylation (Eq. (5)). Recently, the O'Hair group reported that binuclear hydride cations, $\left[\operatorname{LAg}_{2}(\mathrm{H})\right]^{+}$, can catalyze the decarboxylation of $\mathrm{HCOOH}$ in conjunction with specific ligands [67,130]. As an example, $\left[\mathrm{Ph}_{3} \mathrm{PAg}_{2}(\mathrm{H})\right]^{+}$is highly selective in the decarboxylation of $\mathrm{HCOOH}$, while $\left[\left(\mathrm{Ph}_{3} \mathrm{P}\right)_{2} \mathrm{Ag}_{2}(\mathrm{H})\right]^{+}$is unreactive. The $\mathrm{Ph}_{3} \mathrm{P}$ ligand serves to reshape the geometry of the binuclear $\left[\mathrm{Ag}_{2}(\mathrm{H})^{+}\right]$scaffold and trigger the decarboxylation reactivity of this species with $\mathrm{HCOOH}$. This is a key step in the selective catalytic synthesis of $\mathrm{CO}_{2}$ from $\mathrm{HCOOH}$. These gas-phase results can be employed to assist in achieving the selective decarboxylation of
$\mathrm{HCOOH}$ in the condensed phase $[67,130]$. Although such studies are rather rare, the importance of gas-phase work is clear, because the resulting data allow the rational design of catalysts in related condensed phase studies.

The coinage metal-mediated decarboxylative coupling of allyl acetate $[68,69]$ is shown in Fig. 15. There has been considerable effort devoted to developing metal catalysts that can catalyze the decarboxylation reaction of allyl esters as a means of forming new $\mathrm{C}-\mathrm{C}$ bonds [135]. Fig. 15 demonstrates that both the organometallic $\left[\mathrm{CH}_{3} \mathrm{CuCH}_{3}\right]^{-}$[68] anion and coinage metal cations $\left[\mathrm{CH}_{3} \mathrm{M}_{1} \mathrm{M}_{2}\right]^{+}$[69] can promote the decarboxylative $\mathrm{C}-\mathrm{C}$ bond coupling of allyl acetate via a simple two-step process. In the case of $\left[\mathrm{CH}_{3} \mathrm{CuCH}_{3}\right]^{-}$catalyzed decarboxylative coupling, the first step is a cross-coupling reaction of the anion with $\mathrm{C}_{3} \mathrm{H}_{5} \mathrm{O}_{2} \mathrm{CCH}_{3}$ to yield $\left[\mathrm{CH}_{3} \mathrm{CuO}_{2} \mathrm{CCH}_{3}\right]^{-}$as the major product. The second step involves collision-induced decarboxylation to reform $\left[\mathrm{CH}_{3} \mathrm{CuCH}_{3}\right]^{-}$, thereby completing the catalytic cycle. Reactivity studies of $\left[\mathrm{CH}_{3} \mathrm{M}_{1} \mathrm{M}_{2}\right]^{+}$catalysis have demonstrated that the catalytic cycle can be tuned by varying the composition of the metal core [69]. In the first step of such reactions, $\left[\mathrm{CH}_{3} \mathrm{Cu}_{2}\right]^{+},\left[\mathrm{CH}_{3} \mathrm{AgCu}\right]^{+}$, or $\left[\mathrm{CH}_{3} \mathrm{Ag}_{2}\right]^{+}$undergoes an ion-molecule reaction with $\mathrm{C}_{3} \mathrm{H}_{5} \mathrm{O}_{2} \mathrm{CCH}_{3}$ to generate $\left[\mathrm{CH}_{3} \mathrm{CO}_{2} \mathrm{Cu}_{2}\right]^{+}$ $\left[\mathrm{CH}_{3} \mathrm{CO}_{2} \mathrm{AgCu}\right]^{+}$, or $\left[\mathrm{CH}_{3} \mathrm{CO}_{2} \mathrm{Ag}_{2}\right]^{+}$. In the second step, the acetate species undergoes collision-induced dissociation to give $\left[\mathrm{CH}_{3} \mathrm{M}_{1} \mathrm{M}_{2}\right]^{+}$and close the catalytic cycle. Although all three metal acetates will undergo decarboxylation, the resulting products and their yields vary considerably. Only $\left[\mathrm{CH}_{3} \mathrm{Cu}_{2}\right]^{+}$and $\left[\mathrm{CH}_{3} \mathrm{AgCu}\right]^{+}$undergo the $\mathrm{C}-\mathrm{C}$ coupling reaction, in yields of $52.7 \%$ and $1.2 \%$, respectively. Overall, therefore, $\left[\mathrm{CH}_{3} \mathrm{Cu}_{2}\right]^{+}$is the superior decarboxylative coupling catalyst, since it gives the highest yield of the desired product for both steps. This result may be attributed to the greater strength of the $\mathrm{Cu}-\mathrm{O}$ bond [136], which prevents the competitive loss of the metal cation in the decarboxylation step, thereby increasing the yield of $\left[\mathrm{CH}_{3} \mathrm{Cu}_{2}\right]^{+}$and lowering the barrier for oxidative addition to copper.

\section{Concluding remarks}

This review summarizes the latest advances in gas-phase catalytic cycles mediated by metal species. The application of mass spectrometric techniques and quantum chemistry calculations has been demonstrated to be an effective means of exploring the kinetics, thermodynamics, and mechanisms of a large number of ion-molecule catalytic reactions. Recent advances related to the decarboxylation of formic acid by $\left[\operatorname{LAg}_{2}(\mathrm{H})\right]^{+}[67]$ have shown that gas-phase studies are directly applicable to the rational design of related condensed-phase catalysts. Although several remarkable factors affecting the efficiency of catalytic cycles have been identified, such as the charged state of the metal species, the electronic structures, the nature of different metals, and the doping effect, there are many unresolved issues. As an example, in the case of catalytic $\mathrm{CO}$ oxidation, the activation and dissociation of molecular $\mathrm{O}_{2}$ in the (open-shell) triplet ground state has not yet been realized when using closed-shell clusters. The available gas-phase clusters capable of promoting $\mathrm{CO}$ oxidation by molecular $\mathrm{O}_{2}$ all 
have open-shell electronic structures and multiple noble metal atoms are typically required. The latest advances in cluster-confined single gold or platinum atoms allow the effective catalysis of $\mathrm{CO}$ oxidation by molecular $\mathrm{O}_{2}$. These species also allow the study of the mechanistic details of the unexpected reactivity and selectivity of single-atom catalysts. In contrast, the details of the catalytic functionalization of $\mathrm{CH}_{4}$ are far from clear. Even though atomic noble metal ions have been shown to catalyze the conversion of $\mathrm{CH}_{4}$, the catalytic cycle is highly complex and much less selective. Cluster-confined single noble metal atoms, in their current state of development, can only induce the elementary activation and conversion of $\mathrm{CH}_{4}$, and a complete catalytic cycle has not been reported. In future, significant efforts will have to be devoted to the study of such gas-phase catalytic systems.

\section{References}

[1] B. Grzybowska-Świerkosz, Top. Catal., 2000, 11, 2-42.

[2] I. E. Wachs, Catal. Today, 2005, 100, 79-94.

[3] W. X. Wang, A. D. Liang, S. J. Lippard, Acc. Chem. Res., 2015, 48, 2632-2639.

[4] S. Sirajuddin, A. C. Rosenzweig, Biochemistry, 2015, 54, 2283-2294.

[5] R. Banerjee, Y. Proshlyakov, J. D. Lipscomb, D. A. Proshlyakov, Nature, 2015, 518, 431-434.

[6] R. A. J. O'Hair, G. N. Khairallah, J. Clust. Sci., 2004, 15, 331-363.

[7] D. K. Böhme, H. Schwarz, Angew. Chem. Int. Ed., 2005, 44, 2336-2354.

[8] R. Burgert, H. Schnöckel, A. Grubisic, X. Li, S. T. Stokes, K. H. Bowen, G. F. Ganteför, B. Kiran, P. Jena, Science, 2008, 319, 438-442.

[9] Y. Gong, M. F. Zhou, L. Andrews, Chem. Rev., 2009, 109, 6765-6808.

[10] P. J. Roach, W. H. Woodward, A. W. Castleman Jr., A. C. Reber, S. N. Khanna, Science, 2009, 323, 492-495.

[11] K. R. Asmis, Phys. Chem. Chem. Phys., 2012, 14, 9270-9281.

[12] S. M. Lang, T. M. Bernhardt, Phys. Chem. Chem. Phys., 2012, 14, 9255-9269.

[13] Y. X. Zhao, X. N. Wu, J. B. Ma, S. G. He, X. L. Ding, Phys. Chem. Chem. Phys., 2011, 13, 1925-1938.
[14] X. L. Ding, X. N. Wu, Y. X. Zhao, S. G. He, Acc. Chem. Res., 2012, 45, 382-390.

[15] Q. Y. Liu, S. G. He, Chem. J. Chinese U., 2014, 35, 665-688

[16] X. N. Li, H. M. Zhang, Z. Yuan, S. G. He, Nat. Commun., 2016, 7, 11404.

[17] Y. K. Li, Z. Yuan, Y. X. Zhao, C. Y. Zhao, Q. Y. Liu, H. Chen, S. G. He, J. Am. Chem. Soc., 2016, 138, 12854-12860.

[18] Z. Y. Li, H. F. Li, Y. X. Zhao, S. G. He, J. Am. Chem. Soc., 2016, 138, 9437-9443.

[19] Y. X. Zhao, X. N. Li, Z. Yuan, Q. Y. Liu, Q. Shi, S. G. He, Chem. Sci., 2016, 7, 4730-4735.

[20] Y. X. Zhao, Q. Y. Liu, M. Q. Zhang, S. G. He, Dalton Trans., 2016, 45, 11471-11495.

[21] Y. X. Zhao, S. G. He, Prog. Chem. 2016, 28, 401-414.

[22] M. Q. Zhang Y. X. Zhao, S. G. He, Chemistry, 2016, 79, 395-402.

[23] R. A. J. O’Hair, Int. J. Mass Spectrom., 2015, 377, 121-129.

[24] G. N. Schatteburg, Struct. Bond, 2016, 1-40.

[25] H. Schwarz, Coord. Chem. Rev., 2016, DOI: 10.1016/j.ccr.2016. 03.009 .

[26] N. Dietl, M. Schlangen, H. Schwarz, Angew. Chem. Int. Ed., 2012, 51, 5544-5555.

[27] R. A. J. O'Hair, N. J. Rijs, Acc. Chem. Res., 2015, 48, 329-340.

[28] R. A. J. O'Hair, Pure Appl. Chem., 2015, 87, 391-404.

[29] B. T. Qiao, A. Q. Wang, X. F. Yang, L. F. Allard, Z. Jiang, Y. Cui, J. Y. Liu, J. Li, T. Zhang, Nat. Chem., 2011, 3, 634-641.

[30] X. F. Yang, A. Q. Wang, B. T. Qiao, J. Li, J. Y. Liu, T. Zhang, Acc. Chem. Res., 2013, 46, 1740-1748.

[31] M. M. Kappes, R. H. Staley, J. Am. Chem. Soc., 1981, 103, 1286-1287.

[32] M. Brönstrup, D. Schröder, I. Kretzschmar, H. Schwarz, J. N. Harvey, J. Am. Chem. Soc., 2001, 123, 142-147.

[33] V. Blagojevic, M. J. Y. Jarvis, E. Flaim, G. K. Koyanagi, V. V. Lavrov, D. K. Bohme, Angew. Chem. Int. Ed., 2003, 42, 4923-4927.

[34] Y. Shi, K. M. Ervin, J. Chem. Phys., 1998, 108, 1757-1760.

[35] M. L. Kimble, A. Welford Castleman Jr., R. Mitrić, C. Bürgel, V. Bonačić-Koutecký, J. Am. Chem. Soc., 2004, 126, 2526-2535.

[36] V. Blagojevic, G. Orlova, D. K. Bohme, J. Am. Chem. Soc., 2005, 127, 3545-3555.

[37] V. Blagojevic, D. K. Bohme, Int. J. Mass Spectrom., 2006, 254, 152-154.

[38] C. K. Siu, S. J. Reitmeier, I. Balteanu, V. E. Bondybey, M. K. Beyer, Eur. Phys. J. D, 2007, 43, 189-192.

\section{Graphical Abstract}

Chin. J. Catal., 2017, 38: 1515-1527 doi: 10.1016/S1872-2067(17)62782-7

\section{Metal-mediated catalysis in the gas phase: A review}

Xiao-Na Li, Xiu-Ping Zou, Sheng-Gui He*

Institute of Chemistry, Chinese Academy of Sciences;

South China University of Technology

In this review, the experimentally identified gas-phase catalytic cycles mediated by atomic metal ions, bare metal clusters, metal oxide clusters, and metal complexes are summarized with an emphasis on the reactivity of cluster confined single-atom catalysts.

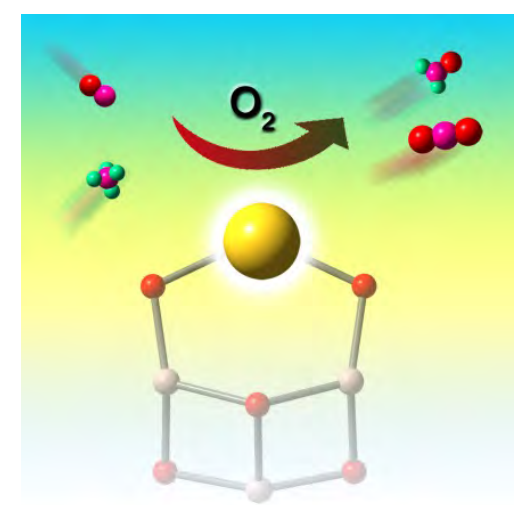


[39] G. E. Johnson, E. C. Tyo, A. W. Castleman Jr., J. Phys. Chem. A, 2008, 112, 4732-4735.

[40] G. E. Johnson, R. Mitrić, E. C. Tyo, V. Bonačić-Koutecký, A. W. Castleman Jr., J. Am. Chem. Soc., 2008, 130, 13912-13920.

[41] E. C. Tyo, M. Nőßler, R. Mitrić, V. Bonačić-Koutecký, A. W. Castleman Jr., Phys. Chem. Chem. Phys., 2011, 13, 4243-4249.

[42] Z. C. Wang, N. Dietl, R. Kretschmer, T. Weiske, M. Schlangen, H. Schwarz, Angew. Chem. Int. Ed., 2011, 50, 12351-12354.

[43] A. Yamada, K. Miyajima, F. Mafuné, Phys. Chem. Chem. Phys., 2012, 14, 4188-4195.

[44] Z. C. Wang, S. Yin, E. R. Bernstein, Phys. Chem. Chem. Phys., 2013, 15, 10429-10434.

[45] J. B. Ma, Z. C. Wang, M. Schlangen, S. G. He, H. Schwarz, Angew. Chem. Int. Ed., 2013, 52, 1226-1230.

[46] S. Yin, Z. C. Wang, E. R. Bernstein, J. Chem. Phys., 2013, 139, 084307.

[47] W. T. Wallace, R. L. Whetten, J. Am. Chem. Soc., 2002, 124, 7499-7505.

[48] H. Häkkinen, U. Landman, J. Am. Chem. Soc., 2001, 123, 9704-9705.

[49] L. D. Socaciu, J. Hagen, T. M. Bernhardt, L. Woste, U. Heiz, H. Häkkinen, U. Landman, J. Am. Chem. Soc., 2003, 125, 10437-10445.

[50] L. D. Socaciu, J. Hagen, J. Le Roux, D. Popolan, T. M. Bernhardt, L. Wöste, Š. Vajda, J. Chem. Phys., 2004, 120, 2078-2081.

[51] Y. Xie, F. Dong, E. R. Bernstein, Catal. Today, 2011, 177, 64-71.

[52] S. M. Lang, I. Fleischer, T. M. Bernhardt, R. N. Barnett, U. Landman, J. Am. Chem. Soc., 2012, 134, 20654-20659.

[53] Z. Y. Li, Z. Yuan, X. N. Li, Y. X. Zhao, S. G. He, J. Am. Chem. Soc., 2014, 136, 14307-14313.

[54] X. N. Li, Z. Yuan, J. H. Meng, Z. Y. Li, S. G. He, J. Phys. Chem. C, 2015, $119,15414-15420$.

[55] K. K. Irikura, J. L. Beauchamp, J. Am. Chem. Soc., 1989, 111, 75-85.

[56] D. Schröder, H. Schwarz, Angew. Chem. Int. Ed., 1990, 29, 1433-1434.

[57] R. Wesendrup, D. Schröder, H. Schwarz, Angew. Chem. Int. Ed., 1994, 33, 1174-1176.

[58] D. Schröder, H. Schwarz, D. E. Clemmer, Y. M. Chen, P. B. Armentrout, V. Baranov, D. K. Böhme, Int. J. Mass Spectrom. Ion Processes, 1997, 161, 175-191.

[59] M. Brönstrup, D. Schröder, H. Schwarz, Organometallics, 1999, 18, 1939-1948.

[60] A. Božović, S. Feil, G. K. Koyanagi, A. A. Viggiano, X. H. Zhang, M. Schlangen, H. Schwarz, D. K. Bohme, Chem. Eur. J., 2010, 16, 11605-11610.

[61] S. M. Lang, T. M. Bernhardt, R. N. Barnett, U. Landman, Angew. Chem. Int. Ed., 2010, 49, 980-983.

[62] S. M. Lang, T. M. Bernhardt, R. N. Barnett, U. Landman, J. Phys. Chem. C, 2011, 115, 6788-6795.

[63] S. M. Lang, A. Frank, T. M. Bernhardt, Catal. Sci. Technol., 2013, 3, 2926-2933.

[64] T. Waters, R. A. J. O’Hair, A. G. Wedd, Int. J. Mass Spectrom., 2003, 228, 599-611.

[65] R. A. J. O'Hair, A. K. Vrkic, P. F. James, J. Am. Chem. Soc., 2004, 126, 12173-12183.

[66] G. N. Khairallah, R. A. J. O’Hair, Int. J. Mass Spectrom., 2006, 254, 145-151.

[67] A. Zavras, G. N. Khairallah, M. Krstić, M. Girod, S. Daly, R. Antoine P. Maitre, R. J. Mulder, S.-A. Alexander, V. Bonačić-Koutecký, P. Dugourd, R. A. J. O’Hair, Nat. Commun., 2016, 7, 11746.

[68] N. J. Rijs, R. A. J. O'Hair, Organometallics, 2012, 31, 8012-8023.

[69] H. A. Sharif, K. L. Vikse, G. N. Khairallah, R. A. J. O’Hair, Organometallics, 2013, 32, 5416-5427.
[70] P. Schnabel, M. P. Irion, K. G. Weil, J. Phys. Chem., 1991, 95, 9688-9694.

[71] P. Schnabel, K. G. Weil, M. P. Irion, Angew. Chem. Int. Ed., 1992, 31, 636-638.

[72] C. Berg, S. Kaiser, T. Schindler, C. Kronseder, G. Niedner-Schatteburg, V. E. Bondybey, Chem. Phys. Lett., 1994, 231, 139-143.

[73] C. Heinemann, H. H. Cornehl, H. Schwarz, J. Organomet. Chem., 1995, 501, 201-209.

[74] R. Wesendrup, H. Schwarz, Organometallics, 1997, 16, 461-466.

[75] E. E. Ferguson, F. C. Fehsenfeld, J. Geophys. Res., 1968, 73, 6215-6223.

[76] D. Schröder, H. Schwarz, Angew. Chem. Int. Ed., 1990, 29, 1431-1433.

[77] A. Dašić, X. Zhao, D. K. Bohme, Int. J. Mass Spectrom., 2006, 254, 155-162.

[78] B. Chiavarino, M. E. Crestoni, S. Fornarini, Chem. Eur. J., 2002, 8, 2740-2746.

[79] M. F. Ryan, D. Stöeckigt, H. Schwarz, J. Am. Chem. Soc., 1994, 116, 9565-9570.

[80] D. Caraiman, D. K. Bohme, J. Phys. Chem. A, 2002, 106, 9705-9717.

[81] T. Waters, G. N. Khairallah, S. A. S. Y. Wimala, Y. C. Ang, R. A. J. O'Hair, A. G. Wedd, Chem. Commun., 2006, 4503-4505.

[82] V. Blagojevic, A. Božović, G. Orlova, D. K. Bohme, J. Phys. Chem. A, 2008, 112, 10141-10146.

[83] M. Andersson, A. Rosén, J. Chem. Phys., 2002, 117, 7051-7054.

[84] S. W. Buckner, J. R. Gord, B. S. Freiser, J. Am. Chem. Soc., 1988, 110, 6606-6612.

[85] T. Waters, R. A. J. O'Hair, A. G. Wedd, J. Am. Chem. Soc., 2003, 125, 3384-3396.

[86] H. J. Freund, G. Meijer, M. Scheffler, R. Schlögl, M. Wolf, Angew. Chem. Int. Ed., 2011, 50, 10064-10094.

[87] T. Fujitani, I. Nakamura, Angew. Chem. Int. Ed., 2011, 50, 10144-10147.

[88] J. Guzman, S. Carrettin, J. C. Fierro-Gonzalez, Y. L. Hao, B. C. Gates, A. Corma, Angew. Chem. Int. Ed., 2005, 44, 4778-4781.

[89] G. I. Panov, K. A. Dubkov, E. V. Starokon, Catal. Today, 2006, 117, 148-155.

[90] S. Carrettin, Y. L. Hao, V. Aguilar-Guerrero, B. C. Gates, S. Trasobares, J. J. Calvino, A. Corma, Chem. Eur. J., 2007, 13, 7771-7779.

[91] J. C. Fierro-Gonzalez, J. Guzman, B. C. Gates, Top. Catal., 2007, 44, 103-114.

[92] M. Jansen, Chem. Soc. Rev., 2008, 37, 1826-1835.

[93] A. Roldán, J. M. Ricart, F. Illas, G. Pacchioni, J. Phys. Chem. C, 2010, 114, 16973-16978.

[94] I. X. Green, W. J. Tang, M. Neurock, J. T. Yates Jr., Angew. Chem. Int. Ed., 2011, 50, 10186-10189.

[95] I. X. Green, W. J. Tang, M. Neurock, J. T. Yates Jr., Acc. Chem. Res., 2014, 47, 805-815.

[96] D. Widmann, E. Hocking, R. J. Behm, J. Catal., 2014, 317, 272-276.

[97] X. N. Li, Z. Y. Li, H. F. Li, S. G. He, Chem. Eur. J., 2016, 22, 9024-9029.

[98] V. I. Pârvulescu, P. Grange, B. Delmon, Catal. Today, 1998, 46, 233-316.

[99] M. Dabros, P. R. Emery, V. R. Thalladi, Angew. Chem. Int. Ed., 2007, 46, 4132-4135.

[100] Z. P. Liu, S. J. Jenkins, D. A. King, J. Am. Chem. Soc., 2004, 126, 10746-10756.

[101] G. K. Koyanagi, D. K. Bohme, J. Phys. Chem. A, 2001, 105, 8964-8968. 
[102] V. V. Lavrov, V. Blagojevic, G. K. Koyanagi, G. Orlova, D. K. Bohme, J. Phys. Chem. A, 2004, 108, 5610-5624.

[103] O. P. Balaj, I. Balteanu, T. T. J. Roßteuscher, M. K. Beyer, V. E. Bondybey, Angew. Chem. Int. Ed., 2004, 43, 6519-6522.

[104] Z. C. Wang, X. N. Wu, Y. X. Zhao, J. B. Ma, X. L. Ding, S. G. He, Chem. Phys. Lett., 2010, 489, 25-29.

[105] X. N. Wu, X. L. Ding, S. M. Bai, B. Xu, S. G. He, Q. Shi, J. Phys. Chem. C, 2011, 115, 13329-13337.

[106] J. B. Ma, B. Xu, J. H. Meng, X. N. Wu, X. L. Ding, X. N. Li, S. G. He, J. Am. Chem. Soc., 2013, 135, 2991-2998.

[107] X. L. Ding, Y. X. Zhao, X. N. Wu, Z. C. Wang, J. B. Ma, S. G. He, Chem. Eur. J., 2010, 16, 11463-11470.

[108] Z. C. Wang, X. N. Wu, Y. X. Zhao, J. B. Ma, X. L. Ding, S. G. He, Chem. Eur. J., 2011, 17, 3449-3457.

[109] L. H. Tian, T. M. Ma, X. N. Li, S. G. He, Dalton Trans., 2013, 42, 11205-11211.

[110] D. Widmann, R. J. Behm, Acc. Chem. Res., 2014, 47, 740-749.

[111] A. P. Woodham, G. Meijer, A. Fielicke, Angew. Chem. Int. Ed., 2012, 51, 4444-4447.

[112] M. L. Kimble, N. A. Moore, G. E. Johnson, A. W. Castleman, Jr., C. Buergel, R. Mitrić, V. Bonačić-Koutecký, J. Chem. Phys., 2006, 125, 204311/1-204311/14.

[113] D. Y. Tang, Y. Q. Zhang, C. W. Hu, Acta Chim. Sin., 2008, 66, 1501-1507.

[114] J. M. Thomas, R. Raja, D. W. Lewis, Angew. Chem. Int. Ed., 2005, 44, 6456-6482.

[115] Y. Y. Jin, P. P. Hao, J. Ren, Z. Li, Prog.Chem., 2015, 27, 1689-1704.

[116] M. Valden, X. Lai, D. W. Goodman, Science, 1998, 281, 1647-1650.

[117] B. Yoon, H. Häkkinen, U. Landman, A. S. Wörz, J. M. Antonietti, S. Abbet, K. Judai, U. Heiz, Science, 2005, 307, 403-407.

[118] I. X. Green, W. J. Tang, M. Neurock,J. T. Yates Jr., Science, 2011, $333,736-739$
[119] A. L. Allred, J. Inorg. Nucl. Chem., 1961, 17, 215-221.

[120] Z. Zakaria, S. K. Kamarudin, Renew. Sust. Energy Rev., 2016, 65, 250-261.

[121] B. Z. Han, Y. Yang, Y. Y. Xu, U. J. Etim, K. Qiao, B. J. Xu, Z. F. Yan, Chin. J. Catal., 2016, 37, 1206-1215.

[122] R. G. Bergman, Nature, 2007, 446, 391-393.

[123] V. N. Cavaliere, D. J. Mindiola, Chem. Sci., 2012, 3, 3356-3365.

[124] B. G. Hashiguchi, S. M. Bischof, M. M. Konnick, R. A. Periana, Acc. Chem. Res., 2012, 45, 885-898.

[125] H. Schwarz, P. González-Navarrete, J. Li, M. Schlangen, X. Y. Sun, T. Weiske, S. D. Zhou, Organometallics, 2017, 36, 8-17.

[126] M. Pavlov, M. R. A. Blomberg, P. E. M. Siegbahn, R. Wesendrup, C. Heinemann, H. Schwarz, J. Phys. Chem. A, 1997, 101, 1567-1579.

[127] Y. X. Zhao, Z. Y. Li, Z. Yuan, X. N. Li, S. G. He, Angew. Chem. Int. Ed., 2014, 53, 9482-9486.

[128] K. Saito, T. Shiose, O. Takahashi, Y. Hidaka, F. Aiba, K. Tabayashi, J. Phys. Chem. A, 2005, 109, 5352-5357.

[129] W. I. Dzik, P. P. Lange, L. J. Goossen, Chem. Sci., 2012, 3, 2671-2678.

[130] A. Zavras, J. M. White, R. A. J. O'Hair, Dalton Trans., 2016, 45, 19408-19415.

[131] M. C. Libby, P. C. Watson, M. A. Barteau, Ind. Eng. Chem. Res., 1994, 33, 2904-2912.

[132] L. J. Goossen, N. Rodríguez, C. Linder, P. P. Lange, A. Fromm, ChemCatChem, 2010, 2, 430-442.

[133] A. Boddien, F. Gärtner, C. Federsel, P. Sponholz, D. Mellmann, R. Jackstell, H. Junge, M. Beller, Angew. Chem. Int. Ed., 2011, 50, 6411-6414.

[134] M. Grasemann, G. Laurenczy, Energy Environ. Sci., 2012, 5, 8171-8181.

[135] J. D. Weaver, A. Recio, A. J. Grenning, J. A. Tunge, Chem. Rev., 2011, 111, 1846-1913.

[136] H. T. Deng, P. Kebarle, J. Am. Chem. Soc., 1998, 120, 2925-2931.

\section{气相金属催化反应综述 \\ 李晓娜 ${ }^{\mathrm{a}}$, 邹秀平 ${ }^{\mathrm{a}, \mathrm{b}}$, 何圣贵 ${ }^{\mathrm{a}}{ }^{*}$ \\ a 中国科学院化学研究所, 动态与稳态结构实验室, 北京 100190 \\ b华南理工大学, 化学与化工学院, 广东广州510641}

摘要: 金属催化剂在工业、环境、能源以及生物等过程具有重要的应用. 设计具有特定活性、环境友好型以及室温下具有 反应活性的催化剂, 需要在分子水平对金属催化剂的基元步骤, 活性位点的结构以及催化反应微观机理有充分的认识. 然 而, 由于宏观催化剂表面结构异常复杂, 催化反应常受到溶剂、压力、金属颗粒团聚、催化剂表面缺陷等因素的干扰, 利用 现有实验仪器, 从微观角度探索金属催化反应机理仍具有较大挑战, 因此, 对金属催化剂活性位的结构以及反应微观机理 的认识还不十分清楚.

质谱方法结合现代量子化学理论计算, 提供了在气相条件下实验探索化学反应微观机理的有力工具, 团族反应可在隔 离外界条件、可控以及可重复条件下进行, 可以排除一些难以控制因素的干扰, 可在化学键和分子结构水平认识金属活性 位的结构以及催化反应的微观机理. 气相金属团簇离子可用多种实验方法制备, 与反应物分子反应后可利用多种质谱仪 器探测, 根据实验上所得的具有反应活性的团簇, 结合现代量子化学理论模拟, 得到金属催化反应的基元步骤以及微观反 应机理信息, 所得反应机理信息为宏观催化剂的设计提供重要理论研究基础.

本综述总结了团簇实验上已经探测到的金属单原子离子、金属团簇、金属氧化物团簇和金属化合物催化的气相反应. 反应物分子囊括了大量的无机和有机分子, 包括 $\mathrm{CO}, \mathrm{H}_{2}, \mathrm{CH}_{4}, \mathrm{C}_{2} \mathrm{H}_{2}, \mathrm{C}_{2} \mathrm{H}_{4}, \mathrm{C}_{6} \mathrm{H}_{6}, \mathrm{CH}_{3} \mathrm{OH}, \mathrm{HCOOH}, \mathrm{CH}_{3} \mathrm{COOH}$ 等. 本综述主 要介绍了以下三类催化反应: (1) CO催化氧化; (2) $\mathrm{CH}_{4}$ 催化转化; (3)催化脱羧反应, 并重点关注贵金属单原子掺杂团簇独特 的催化反应性. 单原子催化剂可最大限度地利用有限的贵金属. 在化学反应方面, 单原子催化剂具有特异的反应活性, 选 择性以及稳定性. 本综述对气相团簇反应中报道的两个重要的贵金属单原子掺杂团簇的催化反应进行了详细介绍: (1)金 原子掺杂的 $\mathrm{AuAl}_{3} \mathrm{O}_{3-5}{ }^{+}$团簇为首次报道的可以利用分子氧催化氧化CO的团簇单原子催化剂, 我们对 $\mathrm{Au}$ 原子起催化作用的 
本质原因进行了介绍: (2)铂原子掺杂的 $\mathrm{PtAl}_{3} \mathrm{O}_{5-7}{ }^{-}$团簇能利用分子氧催化氧化 CO, 该研究提出了"电负性阶梯"效应来解释 $\mathrm{Pt}$ 原子催化的微观机理, 且此效应有望对大部分贵金属适用. 此外, 本综述对 CO催化氧化反应和 $\mathrm{CH}_{4}$ 催化转化反应的研究 现状以及尚未解决的问题进行了剖析. 相比CO的催化氧化反应, 科学家对 $\mathrm{CH}_{4}$ 催化转化反应机理的认识还不够深入, 还需 要进一步实验研究, 而团簇单原子催化剂有望在此领域有所突破.

关键词: 金属催化; 团簇; 单原子催化剂; 一氧化碳; 甲烷

收稿日期: 2016-11-31. 接受日期: 2017-01-05. 出版日期: 2017-09-05.

*通讯联系人. 电话: (010)62568330; 传真: (010)62559373; 电子信箱: shengguihe@iccas.ac.cn

基金来源：国家自然科学基金(21303215, 21325314, 21573246); 重大研究计划(2013CB834603); 中科院青促会基金(2016030).

本文的英文电子版由Elsevier出版社在ScienceDirect上出版(http://www.sciencedirect.com/science/journal/18722067). 